\title{
THE CASE FOR COMPREHENSIVE Random Breath Testing Programs in Canada: REVIEWING THE EVIDENCE AND CHALLENGES
}

\author{
Robert Solomon, ${ }^{*}$ ERIKA CHAMBERlain, ${ }^{* *}$ \\ Maria ABdoullaeva, ${ }^{* * *}$ Ben TinHOLT,${ }^{* * * *}$ AND SUZIE CHIODO ${ }^{* * * * *}$
}

Impairment related crashes remain Canada's leading criminal cause of death. In response, this article examines impaired driving rates and enforcement in Canada and argues that random breath testing programs would increase the risk of apprehension, thereby enhancing the deterrent impact of Canada's impaired driving laws. The authors analyze the international experience with random breath testing, explaining that most developed and developing countries, including Australia, New Zealand, and Ireland have implemented random breath testing. These programs have had significant traffic safety benefits and enjoy broad public support.

The authors argue that, while random breath testing legislation may be found to infringe section 8 and is most likely to infringe sections 9 and 10(b) of the Canadian Charter of Rights and Freedoms, it should be upheld under section 1. They argue that the potential benefits of random breath testing in Canada would be substantial, while the effects on individual rights would be modest.
Les collisions causées par l'ivresse au volant demeurent la plus grande cause criminelle de décès au Canada.En réponse, cet article examine les taux de conduite avec facultés affaiblies et l'application des lois au Canada et fait remarquer que les programmes d'alcooltest au hasard augmentent le risque d'arrestation et rehaussent par conséquent l'effet dissuasif des lois en la matière. Les auteurs analysent les expériences internationales relatives aux analyses d'haleine au hasard en précisant que la plupart des pays développés et en développement incluant l'Australie, la Nouvelle-Zélande, et l'Irlande ont adopté les analyses d'haleine au hasard. Ces programmes ont donné de bons résultats en ce qui concerne la sécurité routière et sont généralement acceptés du public.

Les auteurs font remarquer que les analyses d'haleine au hasard pourraient aller à l'encontre de l'article 8 et probablement à l'encontre des articles 9 et 10(b) de la Charte canadienne des droits et libertés, la pratique devrait être maintenue en vertu de l'article 1. Ils font valoir le fait que les avantages potentiels des analyses au hasard au Canada seraient importants alors que les effets sur les droits individuels seraient modestes.

\section{TABLE OF CONTENTS}

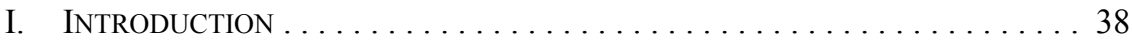

II. THE NEED FOR RANDOM BREATH TESTING IN CANADA . . . . . . . . . . . . . 39

A. CANAdA's IMPAIRED DRIVING RECORD . . . . . . . . . . . . 39

B. Recent Trends and Prospects for Progress $\ldots \ldots \ldots \ldots \ldots . \ldots 42$

C. CANADA'S EXISTING SYSTEM OF

IMPAIRED DRIVING ENFORCEMENT $\ldots \ldots \ldots \ldots \ldots \ldots \ldots$

* $\quad$ Professor, Faculty of Law, University of Western Ontario. The authors wish to acknowledge the advice and research assistance provided throughout the project by Dr B Watson, Centre for Accident Research and Road Safety, Queensland. The authors would like to thank Professor P Hogg, Blake, Cassels \& Graydon LLP, for reviewing a draft of this article and providing helpful comments, as well as Dr R Homel, Griffith University, and Inspector S Doyle, Senior Sergeant R Teale and Sergeant D Brown, Queensland Police Service. The financial support of MADD Canada and the Law Foundation of Ontario is gratefully acknowledged.

** Professor, Faculty of Law, University of Western Ontario.

J*** JD Candidate (2011), University of Western Ontario.

***** JD Candidate (2012), University of Western Ontario.

***** JD Candidate (2011), University of Western Ontario. 
III. THE INTERNATIONAL EXPERIENCE

WITH RANDOM BREATH TESTING . . . . . . . . . . . . . . . . . . . 50

A. INTRODUCTION ......................... 50

B. THE IMPACT OF RANDOM BREATH TESTING ON

IMPAIRED DRIVING DEATHS AND INJURIES $\ldots \ldots \ldots \ldots \ldots \ldots \ldots . \ldots . \ldots 57$

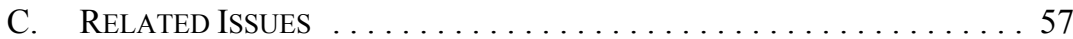

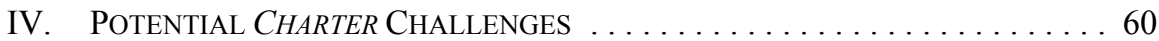

A. SeCtion 8:

UnREASONABLE SEARCH AND SEIZURE $\ldots \ldots \ldots \ldots \ldots \ldots \ldots$

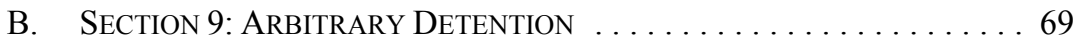

C. Section 10(B): Right to Counsel $\ldots \ldots \ldots \ldots \ldots \ldots \ldots \ldots$

D. SECTION 1:

WHETHER ANY INFRINGEMENTS ARE JUSTIFIED $\ldots \ldots \ldots \ldots \ldots 71$

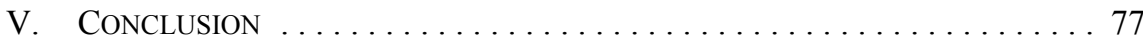

\section{INTRODUCTION}

Despite numerous federal, provincial, and territorial ${ }^{1}$ legislative amendments, countless awareness programs, and other initiatives, impairment related crashes remain Canada's leading criminal cause of death. Although impaired driving deaths in Canada fell significantly from the early 1980s until the late 1990s, virtually no progress has been made since. Faced with similar concerns about the persistence of impaired driving, most developed and developing countries have enacted random breath testing (RBT) programs. It is widely accepted that well-publicized, intensive RBT programs increase the perceived and actual risks of apprehension, and thereby achieve sharp and sustained reductions in impaired driving deaths and injuries.

The House of Commons Standing Committee on Justice and Human Rights, relying in part on this information, unanimously recommended in 2009 that the federal government enact RBT legislation. ${ }^{2}$ The government accepted the Committee's recommendation in principle, and the Department of Justice issued a discussion paper and convened a two-day workshop endorsing RBT in March 2010. ${ }^{3}$ The purpose of the present article is to analyze the current state of impaired driving enforcement in Canada, the international experience with RBT, and to discuss whether federal RBT legislation would violate the Canadian Charter of Rights and Freedoms. ${ }^{4}$

Part II of the article begins with a summary of Canada's impaired driving record followed by a review of factors, including alcohol consumption trends, that are likely to influence future impaired driving rates in Canada. It ends with a discussion of current Canadian

1 Unless otherwise indicated, subsequent references to the provinces should be interpreted as including the territories.

2 House of Commons, Standing Committee on Justice and Human Rights, Ending Alcohol-Impaired Driving: A Common Approach (June 2009) at 13-16 (Chair: Ed Fast) [Ending Alcohol-Impaired Driving].

3 Canada, Department of Justice, Discussion Paper: Modernizing the Transportation Provisions of the Criminal Code, (Ottawa: Department of Justice, 2010) at 10-13.

$4 \quad$ Part I of the Constitution Act, 1982, being Schedule B to the Canada Act 1982 (UK), 1982, c 11 [Charter]. 
impaired driving enforcement and its limited deterrent effect. Part III focuses on the impact that comprehensive RBT programs have had in other countries and examines related issues, including levels of public support for RBT and its cost-effectiveness. Part IV analyzes the Charter challenges that will inevitably be raised in opposition to RBT legislation. This entails a discussion of whether RBT infringes sections 8, 9, and 10(b) of the Charter, and whether any such infringements can be upheld under section 1 as reasonable and demonstrably justified.

We conclude with three assertions. First, in the absence of federal RBT legislation, Canada will continue to have among the poorest impaired driving records of any comparable developed country. Second, the relatively minor costs and inconvenience associated with RBT are far outweighed by its proven traffic safety benefits. Third, RBT should be upheld under the Charter, given the courts' response to other impaired driving enforcement issues and their acceptance of existing random screening programs at customs, airports, courthouses, and other public facilities.

\section{The NeEd FOR RANDOM BREATH TeSting in CANAdA}

\section{A. CANADA'S IMPAIRED DRIVING RECORD}

Impaired driving deaths in Canada peaked in the early 1980s, prompting an unparalleled flurry of federal and provincial legislative amendments. ${ }^{5}$ Research, public health, government, and grassroots organizations launched major public awareness and education programs. Moreover, grassroots organizations like MADD Canada and its predecessors succeeded in putting a human face on the victims of impaired driving. The public, politicians, and the media adopted more critical attitudes towards drinking and driving. ${ }^{6}$ These and other measures led to significant declines in impaired driving deaths and injuries. However, the rate of decline slowed in the mid-1990s and, by 2000, had all but stopped. ${ }^{7}$

5 DR Mayhew, DJ Beirness \& HM Simpson, "Trends in Drinking-Driving Fatalities in Canada Progress Continues" in H Laurell \& F Schlyter, eds, Alcohol, Drugs and Traffic Safety - T2000: Proceedings of the 15th International Conference on Alcohol, Drugs, and Traffic Safety, Stockholm, Sweden, May 22nd-26th, 2000, CD-ROM: (Stockholm: International Council on Alcohol, Drugs, and Traffic Safety (ICADTS), 2000) [ICADTS 2000]. Had the percentage of alcohol-related traffic deaths remained constant relative to total traffic deaths from the peak year in 1982, roughly 32,880 additional Canadians would have been killed by the end of 2007. S Pitel \& R Solomon, Lives Saved (Oakville: MADD Canada, 2010) online: MADD Canada <http:/www.madd.ca/english/research/lives_saved.pdf $>$ [Pitel \& Solomon, Lives Saved]. The federal amendments included the new offences of impaired driving causing death and bodily injury; provisions permitting the police to demand blood samples in certain limited circumstances; mandatory minimum driving prohibitions; and significantly increased minimum and maximum penalties. Criminal Law Amendment Act, 1985, SC 1985, c 19. The amendments at the provincial level included the introduction of 90-day administrative licence suspensions for drivers with blood alcohol concentrations (BACs) at or above .08 percent; lengthier minimum licence suspensions for drivers convicted of a federal impaired driving offence; mandatory education, assessment, and treatment programs; and the introduction of graduated licencing programs for young drivers.

6 For a general discussion of these developments see Mark Asbridge et al, "The Criminalization of Impaired Driving in Canada: Assessing the Deterrent Impact of Canada's First Per Se Law" (2004) 65:4 Journal of Studies on Alcohol and Drugs 450 at 456-58; LC Degutis et al, "A Comparative Analysis of Impaired Driving Laws in the US and Canada: the Impact of Politics, Data and Advocacy" in P Williams \& A Clayton, eds, Proceedings of the 17th International Conference on Alcohol, Drugs and Traffic Safety, 8-13 August 2004, Glasgow, Scotland, CD-ROM: (Glasgow: ICADTS, 2004) [ICADTS 2004]; Robert E Mann et al, "Drinking-Driving Fatalities and Consumption of Beer, Wine and Spirits" (2006) 25:4 Drug and Alcohol Review 321 at 324.

$7 \quad$ Pitel \& Solomon, Lives Saved, supra note 5; DR Mayhew, DJ Beirness \& HM Simpson, "Trends in Drinking-Driving Fatalities in Canada - Progress Stalls" in ICADTS 2004, ibid. 
Impaired driving has proven to be a persistent problem. The subsequent federal ${ }^{8}$ and provincial legislative amendments, ${ }^{9}$ the ongoing awareness and educational campaigns, the introduction of responsible serving practices by municipalities, post-secondary institutions, and the hospitality industry, and the implementation of alternate transportation policies such as designated driver programs have failed to achieve further declines in impaired driving deaths and injuries. The totals in 2008, the latest year for which there are national data, are comparable to the 2000 levels. ${ }^{10}$ It was conservatively estimated ${ }^{11}$ that there were 196,845 impairment related crashes in 2008, which resulted in 1,162 deaths, 68,538 injuries, and 226,522 vehicles damaged in non-injury crashes. ${ }^{12}$ The total financial and social costs of these losses were estimated to be $\$ 21.62$ billion. $^{13}$

Although Parliament enacted amendments in 1999, 2000, and 2007, these related primarily to sentencing matters. See Bill C-82, An Act to amend the Criminal Code (impaired driving and related matters), 36th Parl, 1st Sess, 1999; Bill C-18, An Act to amend the Criminal Code (impaired driving causing death and other matters), 2nd Sess, 36th Parl, 1999; Bill C-9, An Act to amend the Criminal Code (conditional sentence of imprisonment), 1st Sess, 39th Parl, 2006. The 2008 amendments were the most recent and comprehensive. Among other things, they empowered the police to investigate drug impaired driving and to demand that suspected impaired drivers submit to physical coordination tests (i.e., standard field sobriety testing). The amendments also created several new offences, increased penalties, and narrowed two questionable defences that were seen as being abused. See Bill C-2, An Act to amend the Criminal Code and to make consequential amendments to other Acts, 2nd Sess, 39th Parl, 2007, cls 18-26. The 2008 amendments addressed several longstanding gaps in the enforcement and prosecution of impaired driving cases, but they did not significantly increase the law's deterrent effect. Consequently, the amendments are unlikely to have much impact on alcohol-related deaths, injuries and crashes. See Robert Solomon, Erika Chamberlain \& Cory Lynch, "Canada's New Impaired Driving Legislation: Modest Gains and Missed Opportunities" (2010) 56 Crim LQ 51.

Most provinces have enacted several progressive measures in the last ten years including comprehensive graduated licencing programs; zero BAC limits for young and new drivers; increased short-term roadside licence suspensions for driving with a BAC of .05 percent or more; mandatory alcohol interlock programs for federal impaired driving offenders; vehicle impoundment programs; and comprehensive assessment and treatment programs. These measures have been effective and, in our view, have prevented sharp increases in impaired driving deaths. For a review of the provincial reforms see $\mathrm{R}$ Solomon \& E Chamberlain, Rating the Provinces and Territories: The 2009 Report (Oakville: MADD Canada, 2009), online: MADD Canada <http://www.madd.ca/english/research/rtp2009.pdf $>$.

S Pitel \& R Solomon, Estimating the Number and Cost of Impairment-Related Traffic Crashes in Canada: 1999 to 2008 (Oakville: MADD Canada, 2011) at 7-8, online: MADD Canada <http://www. madd.ca/english/research/Estimating\%20Number\%20and\%20Cost\%202011\%20(2008\%20Stats\%20 Report)_FINAL.pdf $>$ [Pitel \& Solomon, Traffic Crashes].

11 Given certain inherent limitations in the coroners' data upon which this estimate is based, it likely significantly understates the total number of impairment related deaths in Canada. For example, if an impaired driver crashes into a vehicle, killing its sober driver and two occupants, it is only the dead driver's BAC that would be reported in the coroner's fatality data. Unless the police recorded the crash as being due to the surviving driver's impairment, all three deaths would be recorded as being nonalcohol-related. Similar problems arise when intoxicated drivers survive crashes in which they kill sober passengers, pedestrians, or bicyclists. See Herb Simpson, Drinking-Driving Statistics in Canada: Does Anyone Really Know How Big the Problem Is? (Ottawa: Traffic Injury Research Foundation (TIRF), 1997) at 53-56. As discussed in Part II.C, below, it is likely that police frequently fail to detect and report the presence of alcohol in crashes. The way that the provinces define an "alcohol-related" traffic death also contributes to under-reporting. For example, Quebec has a narrower definition of an "alcoholrelated death" than the other provinces, excluding deaths among alcohol impaired pedestrians, deaths in off-road crashes, and deaths involving snowmobiles, ATVs, bicycles, and other non-principal vehicle types. See Traffic Injury Research Foundation of Canada, Alcohol-Crash Problem in Canada: 2008 (Ottawa: TIRF, 2010) at 133, online: TIRF <http://www.ccmta.ca/english/committees/rsrp/strid/pdf/ alcohol_crash08_e.PDF> [Crash Problem 2008]. Moreover, a crash in Quebec is only categorized as alcohol-related if the police list alcohol as a "probable cause" of the crash (ibid at 9).

12 Pitel \& Solomon, Traffic Crashes, supra note 10 at 3. Moreover, well over 50,000 additional vehicles were damaged in fatal and personal injury crashes in 2008 (ibid at 8). Ibid at 10 
As indicated, impairment related crashes remain Canada's leading criminal cause of death, claiming almost twice as many lives per year as all types of homicide combined. ${ }^{14}$ Moreover, impaired driving takes a disproportionate toll among young Canadians. ${ }^{15}$ In 2008, 15 - to 25 year-olds constituted 13.7 percent of the population, but they made up almost 33 percent of the alcohol-related traffic deaths. ${ }^{16}$ These alcohol-related crash deaths help to explain why 15- to 19-year-olds are almost 15 times, and 20- to 24-year-olds more than nine times more likely to die per kilometre driven than their parents. ${ }^{17}$ Despite all of the youth awareness and education programs, traffic crashes remain by far the largest single cause of death among 15 to 24 -year-olds, ${ }^{18}$ and approximately 50 percent are alcohol-related. ${ }^{19}$ From a public health perspective, these youth crash deaths represent a major cause of preventable years of life lost, as these victims typically die 50 to 60 years prematurely.

While comparative data must be used with caution, Canada's impaired driving record is poor relative to that of other developed democracies. An international review of 15 countries published in 2000 reported that Canada had the second highest rate of alcohol involvement in fatal crashes. ${ }^{20}$ As the chart below illustrates, a 2001 Transport Canada study found that Canada had the highest rate of impairment among fatally injured drivers of eight Organization for Economic Co-operation and Development (OECD) countries, ${ }^{21}$ even though most of these countries had far higher rates of per capita alcohol consumption. For example, while Germans consumed 64 percent more alcohol per capita than Canadians in 1998, Transport Canada reported that only 11 percent of Germany's fatally injured drivers were legally impaired, as defined by having a BAC of .05 percent or higher. In contrast, 32 percent of Canada's fatally injured drivers were legally impaired, as defined by having a BAC in excess of .08 percent. $^{22}$

In contrast to the 1,162 impairment related crash fatalities in 2008, there were 611 homicides in Canada, which includes the separate offences of murder, manslaughter, and infanticide. Statistics Canada, CANSIM Table 253-0001, Homicide Survey, number and rates (per 100,000 population) of homicide victims, Canada and provinces, annual (Ottawa: Statistics Canada, 2010) [Table 253-0001].

15 Researchers have used various age groupings in reporting youth data. Some researchers divided youth into 16- to 19- and 20- to 24-year-olds, others used 15- to 19- and 20- to 24-year-old groupings, and finally others reported the data in terms of 16 - to 19 - and 20 - to 25 -year-olds. Where possible, we avoided switching between sources that used different age groupings.

16 See Statistics Canada, CANSIM Table 051-0001, Estimates of Population, by age group and sex for July 1, Canada, provinces and territories, annual (persons) (Ottawa: Statistics Canada, 2010); Crash Problem 2008, supra note 11 at 14; Patricia Emery, Dan Mayhew \& Herb Simpson, Youth and Road Crashes: Magnitude, Characteristics and Trends (Ottawa: Traffic Injury Research Foundation, 2008) at 15, online: TIRF < http://www.tirf.ca/publications/PDF_publications/YouthandRoadCrashes_Mag nitudeCharacteristicsandTrends.pdf $>$.

17 Ibid.

18 Statistics Canada, CANSIM Table 102-0540, Deaths, by cause, Chapter XX: External causes of morbidity and mortality (V01 to V89), age group and sex, Canada, annual (number) (Ottawa: Statistics Canada, 2010). In 2006, transport crashes accounted for 39.3 percent of total deaths from all causes among 15- to 19-year-olds, and 28.7 percent of all deaths among 20- to 24-year-olds.

19 Alcohol was involved in 44.3 percent of crash deaths among 16 - to 19 -year-olds, and 55.5 percent of crash deaths among 20 - to 25 -year-olds. Given the conservative nature of the alcohol-related crash death estimates and other factors, it is likely that over 50 percent of youth crash deaths are alcohol-related. Crash Problem 2008, supra note 11 at 14.

$20 \quad \mathrm{~K}$ Stewart et al, "International Comparison of Laws and Alcohol Crash Rates: Lessons Learned" in ICADTS 2000, supra note 5.

21 Transport Canada, Canada's Road Safety Targets to 2010 (Ottawa: Minister of Public Works and Government Services, 2001) at 7, online: Transport Canada $<$ http://www.tc.gc.ca/media/documents/ roadsafety/CRS_Target.pdf $>$ [Road Safety Targets].

22 See respectively, World Health Organization (WHO), Recorded adult per capita consumption, from 1961 Total (Geneva: WHO, 1998), online: WHO <http://apps.who.int/ghodata/?theme=GISAH\& vid=52140>; Road Safety Targets, ibid. 


\section{LEGAL IMPAIRMENT AMONG FATALLY INJURED DRIVERS: SELECTED OECD COUNTRIES, 1997-1998}

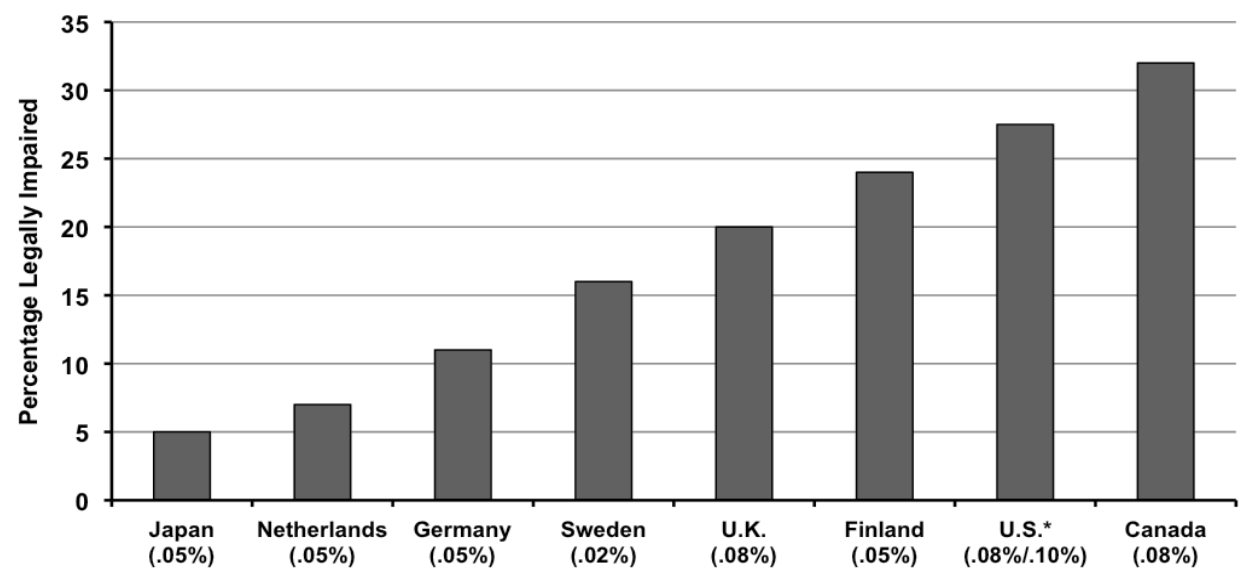

* At the time, the criminal BAC limit was .08 percent in 15 American states and .10 percent in 33 states.

\section{B. Recent Trends And Prospects for Progress}

The results of Canada's national transportation strategy, Road Safety Vision 2010 (RSV), have been extremely disappointing. ${ }^{23}$ The $R S V$ sought a 40 percent reduction in alcoholrelated deaths and injuries among drivers by 2010 compared to the 1996-2001 baseline period. An external mid-term review of the $R S V$ reported that only the Yukon was on track to meet its targeted reductions in alcohol-related deaths, and that no jurisdiction was on track in terms of injuries. In contrast, alcohol-related deaths had increased above the baseline level in five jurisdictions, as had injuries. ${ }^{24}$ The authors were highly critical of the government's legislative inaction in regard to impaired driving. They described the enactment of RBT as a national priority ${ }^{25}$ and stated: "The principles of certainty, severity and celerity are basic and Random Breath Testing (RBT) is the most effective and efficient means of achieving this." ${ }^{26}$ A contemporaneous Transport Canada review reported, without comment, that the $R S V$ had failed to achieve 81 percent of its target reductions in alcohol-related crash deaths. ${ }^{27}$

The upward trends in alcohol availability, per capita consumption, and high-risk drinking in Canada do not augur well for future rates of impaired driving. Increased alcohol availability is associated with increased per capita consumption and binge drinking

23 Mavis Johnson \& Eric Howard, Road Safety Vision 2010: Mid-Term Review, Final Report (Burnaby: Canadian Traffic Safety Institute, 2007), online: Canadian Council of Motor Transport Administrators (CCMTA) <http://www.ccmta.ca/english/pdf/rsv2010_midtermreport_final.pdf $>$ [RSV].

Ibid at 57.

Ibid at 73 .

Ibid at 69.

Paul Gutoskie, Road Safety Vision 2010: 2006 Update (Ottawa: Canadian Council of Motor Transport Administrators, 2008) at 36, online: CCMTA < http://www.ccmta.ca/english/committees/rsrp/rsv/RSF/ presentations/rsv2010_update.pdf>. 
(consuming five or more standard drinks on a single occasion). ${ }^{28}$ In turn, both of these factors have been shown to be predictive of impaired driving deaths and injuries. ${ }^{29}$

The number and types of alcohol-related services and venues have increased, and the restrictions on alcohol advertising, promotions, and other marketing activities have been eased..$^{30}$ Moreover, per capita sales in litres of absolute alcohol increased by about 14 percent from 7.2 percent in 1997 to 8.2 percent in 2009. ${ }^{31}$ Binge drinking has also increased,

For a detailed review, see Thomas Babor et al, Alcohol: No Ordinary Commodity - Research and Public Policy, 2d ed (New York: Oxford University Press, 2010) at 103-46. See also Ross Homel \& Paul Wilson, "Law and Road Safety: Strategies for Modifying the Social Environment, with Particular Reference to Alcohol Control Policies" (1988) 21:2 Austl Crim \& NZJ 104; Robert E Mann \& Lise Anglin, "Alcohol Availability, Per Capita Consumption, and the Alcohol-Crash Problem" in R Jean Wilson \& Robert E Mann, eds, Drinking and Driving: Advances in Research and Prevention (New York: The Guilford Press, 1990) 205 at 205.

29 A considerable body of research indicates that impaired driving crashes increase as per capita alcohol consumption rises. For example, every litre increase in per capita alcohol consumption between 1950 and 1998 in Canada was associated with an increase in accident mortality of 5.9 males and 1.9 females per 100,000. The association between consumption and traffic deaths was statistically significant for both genders. Ole-Jørgen Skog, “Alcohol consumption and fatal accidents in Canada, 1950-98” (2003) 98 Addiction 883 at 888. See also Peter Howat et al, "Preventing Alcohol-Related Traffic Injury: A Health Promotion Approach" (2004) 5:3 Traffic Injury Prevention 208; Joel W Grube \& Kathryn Stewart, "Preventing Impaired Driving Using Alcohol Policy" (2004) 5:3 Traffic Injury Prevention 199; Harold Holder, "Population Drinking and Alcohol Harm: What these Canadian Analyses Tell Us" (2003) 98 Addiction 865. Research indicates that binge drinking is associated with impaired driving crashes in two ways. First, heavy drinking has a significant disinhibiting impact on risk-taking behaviour, including impaired driving. For example, a 2003 American study reported that "[b]inge drinkers were 14 times more likely to drive while impaired by alcohol compared with non-binge drinkers." Timothy S Naimi et al, "Binge Drinking Among US Adults" (2003) 289:1 Journal of the American Medical Association 70 at 70 . Second, the relative risk of crash death rises sharply at the BACs associated with binge drinking. See generally Simin Liu et al, "Prevalence of Alcohol-Impaired Driving: Results From a National Self-reported Survey of Health Behaviors" (1997) 277:2 Journal of the American Medical Association 122; Jürgen Rehm et al, "The Relationship of Average Volume of Alcohol Consumption and Patterns of Drinking to Burden of Disease: An Overview" (2003) 98 Addiction 1209; Benjamin Taylor et al, "Determination of Lifetime Injury Mortality Risk in Canada in 2002 by Drinking Amount per Occasion and Number of Occasions" (2008) 168:10 American Journal of Epidemiology 1119; José Lorenzo Valencia-Martín, Iñaki Galán \& Fernando Rodríguez-Artalejo, "The Joint Association of Average Volume of Alcohol and Binge Drinking with Hazardous Driving Behaviour and Traffic Crashes" (2008) 103 Addiction 749; Cecile A Marczinski, Emily LR Harrison \& Mark T Fillmore, "Effects of Alcohol on Simulated Driving and Perceived Driving Impairment in Binge Drinkers" (2008) 32:7 Alcoholism: Clinical and Experimental Research 1329 at 1330.

For example, Ontario now licences U-Brews, U-Vins, brew pubs, wine pubs, microbreweries, wine outlets in grocery stores, private sector delivery services, sports stadiums, movie theatres, bowling alleys, and a broad network of agency stores and other liquor outlets. The days and hours of on and off-premise alcohol sales have been extended. Patrons can now bring their own wine into designated licenced establishments and golfers can now purchase alcohol from mobile carts while on the course. Licensees can now sell full bottles of liquor, offer one-price food and alcohol packages, host alcohol manufacturers' sampling, marketing events, and theme nights, and provide price incentives to boost alcohol sales. Extra-strength beers, liquor coolers, shooters, and alcoholic energy drinks are now readily available. Alcohol may now be offered as a prize and manufacturers have greater leeway in providing alcohol free of charge. Federal and provincial restrictions on alcohol advertising have been significantly eased and government pre-approval has given way to a system of industry self-regulation. Moreover, the promotion and marketing of alcohol on the internet is largely unregulated. In other provinces, the government monopoly has been repealed and private sector liquor stores have proliferated. For general reviews of alcohol advertising and marketing in Ontario, see B Hovius \& RM Solomon, Alcohol Advertising: A Legal Primer, $2 \mathrm{~d}$ ed (Toronto: Association to Reduce Alcohol Promotion in Ontario, 2001), online: Alcohol Policy Network <http://www.apolnet.ca/thelaw/arapoprimer.pdf >; Rebecca B Fortin \& Benjamin Rempel, The Effectiveness of Regulating Alcohol Advertising: Policies and Public Health (Toronto: Association to Reduce Alcohol Promotion in Ontario, 2005) online: Alcohol Policy Network $<$ http://www.apolnet.ca/resources/pubs/rpt_Effectiveness-Dec05.pdf $>$. For current information on alcohol licencing, advertising, and promotion in Ontario, see the Alcohol and Gaming Commission of Ontario, online: Alcohol and Gaming Commission of Ontario <http://www. agco.on.ca $>$.

Statistics Canada, CANSIM Table 183-0019, Volume of sales of alcoholic beverages in litres of absolute alcohol and per capita 15 Years and over, fiscal years ended March 31, annual (Ottawa: Statistics Canada, 2010). 
particularly among Canadian youth. ${ }^{32}$ Statistics Canada reported that in $2005,64.8$ percent of 15- to 19-year-old current drinkers acknowledged binge drinking at least once in the past year and almost half of these binge drinkers reported doing so 12 or more times. Among 20to 24-year-old current drinkers, 75.9 percent acknowledged binge drinking at least once in the past year, and almost 60 percent of these binge drinkers reported doing so 12 or more times. $^{33}$

The percentage of Canadians who reported driving after drinking in the past 30 days rose from 16.7 percent in 2001 to 17.6 percent in 2007, and to 24.7 percent (representing well over 5.5 million drivers) in $2010 .{ }^{34}$ The percentage that drove when they thought they were intoxicated in the past year rose from 7.3 percent in 2001 to 8.2 percent in 2007 , fell sharply to 5.2 percent in 2008 and then rose to 5.5 percent in $2010 .{ }^{35}$ The authors of the survey suggest that the 2008 decrease may have been due to the 2008 federal amendments and the accompanying publicity, and that the subsequent increases may reflect the waning influence of that legislation.

Roadside surveys conducted in Vancouver, Saanich, and Abbotsford on Wednesday, Friday, and Saturday nights in 2008 found that 9.6 percent of the drivers who agreed to provide a breath sample were positive for alcohol ${ }^{36}$ Comparable data collected in 1995 were available from Vancouver and Saanich. While the percentage of alcohol-positive drivers fell sharply between 1995 (18.7 percent) and 2008 (7.8 percent), the percentage of those with BACs above .08 percent increased from 2 percent to 2.7 percent. ${ }^{37}$ The number of drivers with BACs over .20 percent in 2008 was greater than in 1995 and the subsequent roadside surveys. $^{38}$

Given these trends and, as discussed below, the limited impact of Canada's impaired driving law, there is little cause for optimism. In our view, major strides cannot be made in the absence of effective federal amendments, the most promising of which is RBT.

Statistics Canada, Health Indicators No 82-221-EIX (Ottawa: Statistics Canada, 2000); Statistics Canada, CANSIM Table 105-0431, Frequency of drinking 5 or more drinks on one occasion in the last 12 months, by age group and sex, household population aged 12 and over who are current drinkers, Canada, 2000/01 (Ottawa: Statistics Canada, 2005) [Table 105-0431].

33 Table 105-0431, ibid. The 15-24 age group also has the highest rates of weekly and monthly binge drinking and of consuming five or more drinks on a typical drinking day. EM Adlaf, P Begin \& E Sawka, eds, Canadian Addiction Survey (CAS): A National Survey on Canadians' Use of Alcohol and Other Drugs: Prevalence of Use and Related Harms: Detailed Report (Ottawa: Canadian Centre on Substance Abuse (CCSA), 2005) at 29, 31, online: CCSA <http://www.ccsa.ca/2005\%20CCSA\%20 Documents/ccsa-004028-2005.pdf>.

$34 \quad$ Ward GM Vanlaar \& Robyn D Robertson, The Road Safety Monitor 2010: Drinking and Driving In Canada (Ottawa: Traffic Injury Research Foundation, 2010) at 2, online: TIRF $<$ http://www.tirf.ca/ publications/PDF publications/rsm 2010 DD web.pdf $>$. For other self-reported survey data on drinking and driving, see Douglas J Beirness \& Christopher G Davis, "Driving After Drinking in Canada: Findings from the Canadian Addiction Survey" (2007) 98:6 Canadian Journal of Public Health 476.

$35 \quad$ Vanlaar \& Robertson, ibid at 3.

36 Douglas J Beirness \& Erin E Beasley, Alcohol \& Drug Use Among Drivers: British Columbia Roadside Survey 2008 (Ottawa: Canadian Centre on Substance Abuse, 2009) at 12, online: CCSA <http://www. ccsa.ca/2009\%20CCSA\%20Documents/ccsa0115382009_e.pdf>.

$37 \quad$ Ibid at 17

38 Ibid. 


\section{CANADA's EXISTING SYSTEM OF IMPAIRED DRIVING ENFORCEMENT}

The enactment of RBT legislation would change only one aspect of Canada's impaired driving enforcement process: the grounds on which preliminary breath screening can be demanded. Canadian police currently have a common law power, ${ }^{39}$ and in most provinces express statutory authority ${ }^{40}$ to stop vehicles at random, to inspect the licence, ownership, and insurance documents of drivers, and to question them about their vehicles, driving, and sobriety.

Section 254(2)(b) of the Criminal Code ${ }^{41}$ of Canada authorizes the police to demand a breath sample for analysis on an "approved screening device" (ASD) from a driver who they reasonably suspect has any alcohol in his or her body. ASDs are small, hand-held breath testing machines that are typically carried in police patrol cars. The results of ASD tests are not admissible as evidence of the driver's impairment or BAC in criminal proceedings. Rather, ASDs are used as a preliminary screening tool, which may provide the police with grounds for demanding breath tests on an "approved instrument" under section 254(3.3). ${ }^{42}$

Approved instruments are larger, more sophisticated machines that are kept at the police station or in specially equipped vans. The police can only demand breath tests on an approved instrument if they have reasonable grounds to believe that a driver has committed an impaired driving offence within the last three hours. Since ASDs are usually calibrated to register a "fail" starting at a BAC of .10 percent, a driver's failed ASD test provides the police with reasonable grounds to believe that the driver has committed the federal impaired driving offence of driving with a BAC in excess of .08 percent. ${ }^{43}$ If the Criminal Code's complex and stringent procedures are followed, ${ }^{44}$ readings from the approved instrument are admissible in evidence as proof of the driver's BAC at the time of the offence, in the absence of evidence to the contrary. ${ }^{45}$ Consistent with their function, approved instruments are frequently referred to as "evidentiary breath testing machines."

The current law establishes what is referred to as a "selective breath testing" (SBT) program, because only drivers reasonably suspected of drinking can be tested. There are two main problems with SBT as it operates in Canada. First, police must form their "reasonable suspicion" about a driver's alcohol consumption using their unaided senses. Unlike the situation in some American states, police in Canada do not use passive alcohol sensors or similar technology at sobriety checkpoints. Although the grounds for demanding an ASD test in Canada are not particularly onerous, police often have difficulty making the necessary assessment during the brief interaction that they have with drivers at sobriety checkpoints. ${ }^{46}$

$R v$ Dedman, [1985] 2 SCR 2 at 32-36; $R$ v Orbanski, 2005 SCC 37, [2005] 2 SCR 3 at para 41 [Orbanski].

See e.g. the Ontario Highway Traffic Act, RSO 1990, c H.8, ss 216(1), 33(1), 33(3), 48(1); the British Columbia Motor Vehicle Act, RSBC 1996, c 318, ss 73(1)-(2), 71 .

RSC 1985, c C-46 [Criminal Code].

Ibid.

Ibid, s 253(1)(b).

These tests must be conducted by "qualified technicians" in accordance with the Criminal Code's strict time limits and other procedural requirements. The machines must be designated by the Attorney General, who in turn relies upon an independent scientific test committee. See ibid, s 254(1).

Ibid, s 258(1)(c).

Evelyn Vingilis \& Violet Vingilis, "The Importance of Roadside Screening for Impaired Drivers in Canada" (1987) 29:1 Can J Crim 17 at 22-25. 
Police are most likely to miss experienced drinkers because they exhibit fewer signs of drinking, as well as drivers who do not fit the impaired driving stereotype. ${ }^{47}$

Researchers have questioned the deterrent impact of SBT checkpoints that rely exclusively on the officer's subjective judgement as to whether breath testing is warranted. ${ }^{48}$ For example, Professor Ross Homel, Australia's most prolific RBT researcher, stated in a 1990 article:

$[\mathrm{M}]$ any drivers ... play 'breathalyzer roulette,' perceiving the odds of apprehension are slight and that they can conceal their drinking successfully. Consequently, any method of enforcement that relies on subjective judgments of impairment ... is unlikely to work over the long term simply because the perceived probability of apprehension cannot be maintained at a high level." 49

He noted, for example, that even during a period of intensified enforcement in Queensland, less than 1 percent of the drivers who were stopped were tested. ${ }^{50}$ This would appear to explain a 2006 study that found that drivers who had previously passed through an SBT checkpoint had less fear of being apprehended for impaired driving than drivers who had not done so. ${ }^{51}$

Research indicates that police, using their unaided senses, fail to detect the great majority of drinking drivers even at sobriety checkpoints. An early Swedish government report found that the majority of drivers with BACs of .05 percent to .15 percent, and nearly half of the drivers with BACs above .15 percent, aroused no suspicion when stopped by police at a simulated roadblock. ${ }^{52}$ A 1997 American study reported that the police missed over 60 percent of drivers with BACs above .08 percent, and almost 90 percent of those with BACs of .05-.079 percent. ${ }^{53}$ Other American studies suggest that police fail to detect about 50 percent of drivers with BACs of .10 percent or more, and 75 percent of those with BACs of $.05-.099$ percent. $^{54}$

A Canadian study published in 1982 concluded that approximately 95 percent of drivers with BACs above .08 percent were not detected during an Etobicoke sobriety checkpoint

E Vingilis, EM Adlaf \& L Chung, "Comparison of Age and Sex Characteristics of Police-Suspected Impaired Drivers and Roadside-Surveyed Impaired Drivers" (1982) 14:6 Accident Analysis \& Prevention 425 at 429 .

For a review of a number of early studies on SBT detection rates, see Vingilis \& Vingilis, supra note 46.

Ross J Homel, "Random Breath Testing the Australian Way: A Model for the United States?" (1990) 14:1 Alcohol Health and Research World 70 at 72 [Homel, "Random Breath Testing the Australian Way"].

Ibid.

$51 \quad$ Kenneth H Beck \& Mary L Moser, "Does the Type of Exposure to a Roadside Sobriety Checkpoint Influence Driver Perceptions Regarding Drunk Driving?" (2006) 30:3 American Journal of Health Behavior 268.

52 The Swedish study is cited by Vingilis \& Vingilis, supra note 46 at 22-23; WR Picton, "Legislation to Allow the Safe Release of Potentially Unsafe Drinking Drivers" (1978) 40 CRNS 30. Joann K Wells et al, "Drinking Drivers Missed at Sobriety Checkpoints"(1997) 58:5 Journal of Studies on Alcohol 513 at 516.

$54 \quad$ SA Ferguson, JK Wells \& AK Lund, "The Role of Passive Alcohol Sensors in Detecting AlcoholImpaired Drivers at Sobriety Checkpoints" (1995) 11:1 Alcohol, Drugs, and Driving 23; Ian S Jones \& Adrian K Lund, "Detection of Alcohol-Impaired Drivers Using a Passive Alcohol Sensor" (1986) 14:2 Journal of Police Science and Administration 153 at 157. This earlier study found that the police failed to detect 55 percent of drivers with BACs of .10 percent or more at sobriety checkpoints. 
program. ${ }^{55}$ This is consistent with an earlier Alberta study which found that the police detected only about 8 percent of the drivers with BACs above .08 percent whom they had stopped and checked. ${ }^{56}$ Although these studies are dated, little appears to have changed. In 2009, the House of Commons Standing Committee on Justice and Human Rights reached a similar conclusion on detection rates at sobriety checkpoints. ${ }^{57}$ Indeed, millions of drivers are processed at organized SBT checkpoints each year in Canada, and millions more are subject to SBT processing during routine police patrol activities. ${ }^{58}$ Nevertheless, as will be discussed, relatively few drinking drivers are detected by police and subsequently charged.

The second major problem with the current Canadian law is that, even if detected, many impaired drivers escape criminal liability. Police must convince a court that their subjective assessment at roadside provided a reasonable factual basis for demanding an ASD test. It is common practice for defence counsel to aggressively challenge the officer's basis for demanding these tests. Moreover, some judges have applied a rigorous standard for making the demand. ${ }^{59}$ Unless the driver admits to drinking, police generally require clear visible signs that the driver had consumed alcohol or was driving in an impaired manner to demand an ASD test. If the court finds that there were insufficient grounds to demand the ASD test, the results of the subsequent evidentiary breath test will be excluded from evidence, and the driver will most likely be acquitted. ${ }^{60}$

This situation has contributed to the de facto decriminalization of impaired driving in Canada. In a national survey, Canadian police expressed concerns about the time-consuming nature of processing impaired driving suspects, the weight given to their testimony, and the legal technicalities that allowed impaired drivers to escape criminal liability. ${ }^{61}$ Thirty percent of the officers reported that they sometimes or frequently let impaired drivers off with a

55

Vingilis, Adlaf \& Chung, supra note 47 at 427. See also Evelyn Vingilis et al, "Psychosocial Characteristics of Alcohol-Involved and Nonalcohol-Involved Seriously Injured Drivers" (1994) 26:2 Accident Analysis \& Prevention 195 at 203.

Picton, supra note 52.

Ending Alcohol-Impaired Driving, supra note 2 at 13.

Unfortunately, there are no national data on the number of drivers stopped at organized SBT checkpoints in Canada. An extrapolation based on 2008 and 2009 Calgary police data indicates that approximately four million drivers would be processed per year at organized SBT checkpoints nationwide. Letter from A Miller (Traffic Analyst, Calgary Police Services) to L Knox (Chapter Services Manager, MADD Canada) (3 August 2010). Ontario data, albeit limited, suggest that the total number of drivers stopped at organized SBT checkpoints in Canada may be double or more than the four million figure. For example, the Ontario Provincial Police $(2,616,048)$, Toronto Police $(409,274)$ and Hamilton Police $(152,833)$ reported stopping almost 3,200,000 drivers in 2009 at RIDE spotchecks (i.e., organized SBT checkpoints). Strategic Initiatives Office, Ontario Provincial Police, 2009 Annual Report (Orillia: Ontario Provincial Police, 2010) at 70, online: Ontario Provincial Police <http://www.opp.ca/ ecms/files/250258838.6.pdf>; Toronto Police Service, 2009 Annual Statistical Report (Toronto: Toronto Police Service, 2010) at 27, online Toronto Police Service <http://www.torontopolice.on.ca/ publications/files/reports/2009statsreport.pdf>; Hamilton Police, 2009 Annual Report (Hamilton: Hamilton Police, 2010) at 10, online: Hamilton Police Service <http:/www.hamiltonpolice.on.ca/ NR/rdonlyres/0EEA3D33-511F-482D-B079-BBF6EC317C95/0/The2009Report.pdf>.

$59 \quad$ See e.g. $R v$ Thompson, 2003 SKPC 56, [2003] SJ no 240 (QL); $R v$ Sood, 2005ABPC 201, 389 AR 139.

60 Challenges to officers' grounds for demanding the ASD test appear to figure prominently in acquittals. Robyn Robertson, Ward Vanlaar \& Herb Simpson, National Survey of Crown Prosecutors and Defence Counsel on Impaired Driving (Ottawa: Traffic Injury Research Foundation, 2009) at 68-70, online: Traffic Injury Research Foundation < http://www.tirf.ca/publications/PDF_publications/Lawyers Survey_Report_Final_2009.pdf>.

61 Brian Jonah et al, "Front-line Police Officers' Practices, Perceptions and Attitudes About the Enforcement of Impaired Driving Laws in Canada" (1999) 31 Accident Analysis \& Prevention 421 at $429,432,435$. 
provincial suspension rather than laying criminal charges. ${ }^{62}$ Similarly, a British Columbia police survey reported that almost half of the officers refused to lay Criminal Code impaired driving charges, even if they concluded that the driver was legally impaired. ${ }^{63}$ This trend helps to explain why Canada's 2007 charge rate for impaired driving offences, per 100,000 licenced drivers, was only 40 percent of the American rate. ${ }^{64}$

The inability to effectively detect and prosecute impaired drivers in Canada reduces the deterrent effect of the law. Millions of Canadians continue to drink and drive with little fear of being stopped, let alone charged and convicted. Surveys of drivers and charge and conviction statistics indicate that on average, a person can drive impaired once a week for more than three years before being charged with an impaired driving offence, and for more than six years before being convicted. ${ }^{65}$ Other survey data indicate that charge and conviction rates may be even lower. ${ }^{66}$

RBT addresses both of the problems that undermine the deterrent impact of Canada's current system of impaired driving enforcement. First, by authorizing police to demand an ASD test from any driver, RBT legislation would solve the problem of impaired drivers who pass through SBT checkpoints undetected. It may also speed up the roadside processing of drivers by eliminating the police need to question drivers, closely observe them for visible signs of impairment, and attempt to detect the odour of alcohol on their breath. One leading researcher noted that this intensive scrutiny requires the police "to perform an elaborate charade involving licenses and equipment, all the time 'sniffing the air' for signs of alcohol., ${ }^{\prime 67}$ Second, RBT legislation would encourage police to lay charges once an impaired driver is detected. Police would no longer need to prove in court that they had reasonable grounds to suspect that the driver had consumed alcohol. In turn, this would eliminate a major ground for contesting the admissibility of evidentiary breath test results. ${ }^{68}$ In sum, RBT

Ibid at 426. Moreover, 29 percent of officers reported that they sometimes or frequently took no legal action against impaired drivers but rather simply arranged for them to be taken home by a sober licenced passenger, taxi, or similar means.

Police Services Division, Safe Roads, Safe Communities (Victoria: Ministry of the Attorney General, Public Safety and Regulatory Branch, 2000) at B-4.

64 The Canadian impaired driving charge rate was only one for every 358 licenced drivers, whereas the American rate was one for every 139 licenced drivers. Transport Canada, 2007 Canadian Motor Vehicle Traffic Collision Statistics (Ottawa: Transport Canada, 2010) at 7, online: Transport Canada $<$ http://www.tc.gc.ca/media/documents/roadsafety/tp3322-2007.pdf >; Statistics Canada, CANSIM Table 252-0051, Incident-based crime statistics, by detailed violations, annual (number) (Ottawa: Statistics Canada, 2009) [Table 252-0051]; National Highway Traffic Safety Administration, National Center for Statistics and Analysis, Traffic Safety Facts, 2007 Data (Washington: National Highway Traffic Safety Administration, 2008) at 5, online: National Highway Traffic Safety Administration <http://wwwnrd.nhtsa.dot.gov/Pubs/810993.PDF>.

65 The estimated 10.2 million alcohol-impaired driving trips made in 2006 resulted in only 60,402 individuals being charged, and only 32,594 individuals being convicted of an impaired driving offence in the 2006/07 reporting year. See respectively, Ward Vanlaar et al, The Road Safety Monitor 2006: Drinking and Driving (Ottawa: Traffic Injury Research Foundation, 2006) at 7, online: TIRF $<$ http://www.tirf.ca/publications/PDF_publications/RSM2006_DrinkingDriving. pdf >; Table 252-0051, ibid.

66 Another study using national survey data estimated that Canadian drivers made over 20 million trips within one hour of consuming two or more drinks in the past 12 months. Beirness \& Davis, supra note 34 at 477.

67 R Homel, "Random Breath Testing and Random Stopping Programs in Australia" in RJ Wilson \& RE Mann, eds, Drinking and Driving: Advances in Research and Prevention (New York: Guilford Press, 1990) 159 at 186 [Homel, "Random Stopping Programs in Australia"].

68 As with ASD tests based on reasonable suspicion, ASD tests based on RBT would not be admissible in criminal proceedings but rather would be used solely to screen drivers to determine if evidentiary breath testing is warranted. 
would increase police apprehension rates and address a common means by which impaired drivers currently escape criminal liability.

As in Australia, New Zealand, and other countries, most random breath testing in Canada would likely be conducted at what are called "organized," "fixed," or "stationary" checkpoints. ${ }^{69}$ However, the power to conduct RBT during routine patrol activities, often referred to as "mobile" $\mathrm{RBT}$, is important in rural areas, late at night, or in other circumstances in which low traffic volumes would not merit establishing an organized RBT checkpoint. Moreover, mobile RBT deters drivers who would otherwise believe that they could evade RBT checkpoints. ${ }^{70}$

By increasing apprehension and conviction rates, ${ }^{71}$ comprehensive RBT programs will greatly increase the deterrent impact of Canada's impaired driving law. ${ }^{72}$ This should in turn significantly reduce related deaths and injuries, as the following discussion of the international experience demonstrates.

It is common practice in Australia to stop and test every passing driver, except when necessary to wave drivers through to prevent undue wait times.

70 See generally Homel, "Random Breath Testing the Australian Way," supra note 49 at 74; Dominic Zaal, Traffic Law Enforcement: A Review of the Literature (Clayton, Australia: Monash University Accident Research Centre, 1994) at 41-42, online: Monash University Accident Research Centre $<\mathrm{http}$ ://www.monash.edu.au/muarc/reports/muarc053.pdf $>$; Ward Vanlaar, "Less is More: The Influence of Traffic Count on Drinking and Driving Behaviour" (2008) 40 Accident Analysis \& Prevention 1018. Mobile RBT also contributes to the unpredictability of apprehension. Daniel Nagin states that the behavioural concept of "ambiguity aversion" explains why unpredictability is a key component of deterrence. Daniel S Nagin, "Criminal Deterrence Research at the Outset of the Twenty-First Century" (1998) 23 Crime and Justice 1 at 11. On a broader level, mobile RBT promotes the ubiquity of testing and allows RBT to be integrated into the "core business" of police rather than being considered an addon. Letter from Professor Barry Watson, Director, Centre for Accident Research and Road Safety Queensland, to Robert Solomon (28 June 2011).

71 The impact of RBT on detection and conviction rates will vary among jurisdictions, depending on the pre-existing level and intensity of impaired driving enforcement. For example, comprehensive RBT programs will have their greatest impact in countries that have no or modest sobriety checkpoint programs. RBT will have a smaller, but still significant, impact in countries that already have intensive sobriety checkpoint programs.

72 For a discussion of the role played by the perceived risk of apprehension in deterring impaired driving, see infra note 103; Nagin, supra note 70; Ross Homel, Policing the Drinking Driver: Random Breath Testing and the Process of Deterrence (Canberra, Australia: Department of Transport, 1986), online: Australian Government - Department of Infrastructure and Transport <http://www.infra structure.gov.au/roads/safety/publications/1986/pdf/cr042.pdf $>$ [Homel, Policing the Drinking Driver]; Ross Homel, "Drivers Who Drink and Rational Choice: Random Breath Testing and the Process of Deterrence" in Ronald V Clarke \& Marcus Felson, eds, Routine Activity and Rational Choice: Advances in Criminological Theory (New Brunswick, NJ: Transaction, 1993) vol 5 at 59 [Homel, "Drivers Who Drink"]; Kenneth H Beck et al, "The Relationship between Impaired Driving Crashes and Beliefs about Impaired Driving: Do Residents in High Crash Rate Counties Have Greater Concerns about Impaired Driving?” (2009) 10:2 Traffic Injury Prevention 127; Kenneth H Beck, James C Fell \& Alice F Yan, “A Comparison of Drivers with High Versus Low Perceived Risk of Being Caught and Arrested for Driving Under the Influence of Alcohol” (2009) 10:4 Traffic Injury Prevention 312. 


\section{The INTERNATIONAL EXPERIENCE WITH RANDOM BREATH TESTING}

\section{REPORTED USE OF RANDOM BREATH TESTING IN SELECTED COUNTRIES ${ }^{73}$}

\begin{tabular}{|lll|l|}
\hline & \multicolumn{2}{c|}{ With RBT } & Without RBT \\
\hline Argentina & Germany* & New Zealand & Canada \\
Austria & Greece & Norway & Dominican Republic \\
Australia & Guatemala & Peru & Ecuador \\
Belgium & Honduras & Poland & Panama \\
Brazil & Hungary & Portugal & Russia* \\
Bulgaria & Iceland & South Korea & South Africa \\
Chile & Ireland & Romania & United Kingdom \\
China & Italy & Slovakia & United States \\
Columbia & Japan & Slovenia & Venezuela \\
Costa Rica & Latvia & Spain & \\
Cyprus & Lithuania & Sweden & \\
Czech Republic & Luxembourg & Switzerland & \\
Denmark & Malta* & Turkey & \\
Estonia & Mexico & Ukraine & \\
Finland & Moldova & & \\
France & The Netherlands & & \\
\hline
\end{tabular}

*The sources differed regarding RBT in these countries.

\section{A. INTRODUCTION}

The persistence of impaired driving is not a challenge that is unique to Canada. However, most developed and developing countries have chosen to respond by implementing RBT programs. A 2008 study and earlier international reviews indicate that 46 of 56 countries (82 percent) had an RBT program established under national or, in a few cases, state/territorial legislation. ${ }^{74}$ Finland, Sweden, and France introduced RBT in the late 1970 s, followed by most Australian jurisdictions in the $1980 \mathrm{~s} .{ }^{75}$ Most other European countries and New Zealand enacted RBT legislation in the 1990s. ${ }^{76}$ In 2003 the European Commission recommended that Alliance, 2009) at 13 [Worldwide]; Kathryn Stewart, On DWI Laws in Other Countries (Washington, DC: National Highway Traffic Safety Administration, 2000) at 40-48, online: National Highway Traffic Safety Administration < http://www.nhtsa.gov/people/injury/research/pub/DWIothercountries/dwiother countries.html>; Ellen Townsend, Franziska Achterberg \& Timmo Janitzek, Traffic Law Enforcement Across the EU: An Overview (Brussels: European Transport Safety Council, 2006), online: European Transport Safety Council <http://www.etsc.eu/documents/ETS\%20May\%202006.pdf $>$ [EU Traffic Law].

74 See generally ibid.

75 Worldwide, ibid; WHO Regional Office for Europe, European Status Report on Alcohol and Health 2010 (Geneva: WHO, 2010) at 44-45 [WHO Report]; EU Traffic Law, ibid at 54, 89; Homel, "Random Stopping Programs in Australia," supra note 67 at 170 (Table 7.1). 
all member states in the European Union introduce comprehensive RBT legislation. ${ }^{77}$ Ireland, the most recent country to do so, initiated its RBT program in $2006 .^{78}$

\section{B. THE IMPACT OF RANDOM BREATH TESTING ON IMPAIRED DRIVING DEATHS AND INJURIES}

\section{RANDOM BREATH TESTING IN AUSTRALIA}

The Australian RBT programs are the best documented and most widely studied, with RBT having first been introduced in Victoria in $1976 .{ }^{79}$ By the end of the 1980s, RBT was in use throughout Australia and had become the country's "central countermeasure against drinking and driving." Australia's RBT programs have been subject to thorough academic scrutiny throughout their history. The early research provided compelling evidence that RBT programs had an immediate and significant impact on impaired driving deaths and injuries, even in the states that had pre-existing SBT programs. However, these studies also established that the positive impact of RBT will wane over time if testing levels and publicity fall. The more recent Australian studies have focused on identifying best practices, maximizing the impact of police resources, and sustaining and enhancing the long-term effects of RBT.

The early studies showed that RBT could have a dramatic impact on road crashes. For example, the introduction of RBT in New South Wales was reported to have caused "an immediate 90 percent decline in road deaths, which soon stabilized at a rate approximately $22 \%$ lower than the average for the previous six years." ${ }^{81}$ Another author noted that, in the space of only 20 weeks, RBT had prevented some 200 fatalities and thousands of hospital admissions. ${ }^{82}$ A 1997 review of the early data concluded that the number of fatal road crashes fell by 48 percent during the first year. ${ }^{83}$ Given these dramatic results, it is not surprising that

European Commission, Press Release, IP/03/1436, "Commission Calls for Better Enforcement of Road Safety Rules” (22 October 2003) online: Europa <http://europa.eu/rapid/pressReleasesAction.do? reference $=\mathrm{IP} / 03 / 1436 \&$ format $=$ HTML\&aged $=0 \& 1 \mathrm{l}=$ hu $\&$ guiLanguage $=$ en $>$.

78 Timmo Janitzek \& Ellen Townsend, Traffic Law Enforcement across the EU: Time for a Directive (Brussels: European Transport Safety Council, 2006) at 15.

79 The other Australian states and territories followed. In 1988, Queensland became the last Australian jurisdiction to enact RBT. Homel, "Random Stopping Programs in Australia," supra note 67 at 170-71. Zaal, supra note 70 at 38, citing James Dunbar, "Drinking and Driving: Global Perspectives: United Kingdom" in Effective Strategies to Combat Drinking and Driving: An Edited Collection of Papers Presented at the International Congress on Drinking and Driving, Edmonton, Alberta, Canada, March 28-30, 1990 (Edmonton: Alberta Solicitor General, 1990) 25 at 27: "the single most important countermeasure for drinking and driving is random breath testing."

81 In fairness, these spectacular reductions were achieved at a time when the magnitude of the impaired driving problem in Australia significantly exceeded the current Canadian situation. Consequently, the introduction of a comprehensive RBT program in Canada would not likely generate such dramatic results. Homel, "Random Breath Testing the Australian Way," supra note 49 at 70.

82 George Paciullo, "Random breath testing in New South Wales" (1983) 1:1 The Medical Journal of Australia 620 at 620 .

83 J Henstridge, R Homel \& P Mackay, The Long-Term Effects of Random Breath Testing in Four Australian States: A Time Series Analysis (Canberra: Federal Office of Road Safety, 1997) at 104 (Table 7.1), online: Australian Government Department of Infrastructure and Transport <http://www. infrastructure.gov.au/roads/safety/publications/1997/Alc_Random.aspx $>$. These authors also estimated that the New South Wales RBT program prevented $20 \overline{4}$ fatal, 522 serious, and 686 single vehicle nighttime crashes in the first 44 days alone. See also Ian Kearns et al, "An Overview of the Random Breath Testing Trial in New South Wales" (1987) 86 Alcohol, Drugs and Traffic Safety 429 at 430. 
"[m] any early reactions to RBT by police, the medical profession and the media could only be described as euphoric." $" 84$

RBT generated significant, albeit less spectacular, declines in crashes in other Australian states and territories. For example, Tasmania's RBT program was credited with reducing all serious crashes by 24 percent in its first year. ${ }^{85}$ Substantial reductions were also achieved in jurisdictions where RBT replaced existing SBT programs, as would be the case in Canada. For example, Queensland's RBT program resulted in a 35 percent reduction in fatal crashes, whereas the previous SBT program had generated only a 15 percent reduction. ${ }^{86}$ Using a different methodology, a second study found that Queensland's introduction of RBT resulted in a 29 percent reduction in alcohol-related fatalities. ${ }^{87}$

Similarly, in a three month period shortly after RBT replaced the existing SBT program in Western Australia, ${ }^{88}$ it achieved a 23 percent decrease in nighttime traffic deaths and injuries compared to the same period the previous year. ${ }^{89}$ A subsequent review of the introduction of RBT in Western Australia noted that, while there were some problems with the data, the impact of the RBT program was invariably greater than that of the preceding SBT program. ${ }^{90}$

Some of the RBT programs were less effective than others, ${ }^{91}$ and the impact of even the initially strong programs tended to wane over time. ${ }^{92}$ Several jurisdictions increased enforcement levels and publicity in an attempt to replicate the successes of New South Wales and Tasmania. ${ }^{93}$ For example, Victoria dramatically intensified its RBT program, conducting almost 1.8 million RBT tests between July 1989 and June $1991 .^{94}$ This initiative was credited with reducing fatal crashes in Melbourne during high alcohol hours by 19-24 percent in $1990 .{ }^{95}$ A leading expert attributed these reductions to increased enforcement, greater

Homel, Policing the Drinking Driver, supra note 72 at 15.

These reductions occurred in the first three months, after which no further benefits of RBT could be measured. Henstridge, Homel \& Mackay, supra note 83 at 104 (Table 7.1). Ibid at 102 (Table 6.9).

B Watson, G Fraine \& L Mitchell, "Enhancing the effectiveness of RBT in Queensland" in Prevention of Alcohol Related Road Crashes: Social and Legal Approaches Conference (Brisbane: Griffith University, 1994) 31 at 43.

Western Australia introduced a random stopping program in 1980, which was intensified in the 18 months preceding the enactment of RBT legislation. As noted earlier in the text, one commentator described the intensified random stopping program as "back-door" or "de facto" RBT, in which "the police were required to perform an elaborate charade involving licenses and equipment, all the time 'sniffing the air' for signs of alcohol." Despite being labelled as back-door or de facto RBT, the intensified random stopping program was the functional equivalent of an intensive SBT program. Homel, "Random Stopping Programs in Australia," supra note 67 at 186.

This significant reduction was achieved even though the police were only testing about 50 percent of the drivers who were stopped under the RBT program. Ibid at 187.

Henstridge, Homel \& Mackay, supra note 83 at 85.

Homel, "Random Stopping Programs in Australia," supra note 67 at 73.

Zaal, supra note 70 at 67.

As noted, the New South Wales RBT program had the most immediate and substantial impact on fatalities, which generated a long-term reduction of 15 percent. However, this ongoing degree of effectiveness "was achieved only through the sustained increases in overall enforcement levels." Henstridge, Homel \& Mackay, supra note 83 at 50.

Glenn Sullivan, Antonietta Cavallo \& Alan Drummond, An Overview of Random Breath Testing Operations in Victoria 1989-1991 (Melbourne: Transport Accident Commission, 1992) at 1, online: Monash University Accident Research Centre <http:/www.monash.edu.au/muarc/reports/muarc 040.pdf>.

Antonietta Cavallo \& Max Cameron, Evaluation of a Random Breath Testing Initiative In Victoria 1990 \& 1991, Summary Report (Melbourne: Transport Accident Commission, 1992) at 24, online: Monash University Accident Research Centre <http://www.monash.edu.au/muarc/reports/muarc 039.pdf>. 
publicity, the use of mobile RBT alongside stationary RBT, and sustaining the program year round. $^{96} \mathrm{~A}$ comprehensive study in Queensland several years later reached similar conclusions on the key elements of effective RBT programs. ${ }^{97}$

The most comprehensive review of the Australian RBT programs was a time series analysis of the long-term effects of RBT in four jurisdictions published in $1997 .{ }^{98} \mathrm{In}$ conducting the study, the authors controlled various confounding factors including other impaired driving countermeasures such as lowering the legal BAC limit to .05 percent. Consistent with earlier research, the 1997 study identified four essential elements of successful RBT programs. First, maximizing RBT's deterrent impact requires high levels of testing. The equivalent of at least one-third of licenced drivers must be tested each year, ${ }^{99}$ but even higher testing levels are preferable. ${ }^{100}$ Second, the program should be extensively publicized, focusing specifically on the high-risk of apprehension. Third, enforcement should include both mobile RBT and high visibility stationary RBT checkpoints. Fourth, in order to sustain the ongoing deterrent impact of an RBT program, enforcement and publicity levels must be maintained. ${ }^{101}$ The RBT program in New South Wales included these elements from the outset and was regarded as the most successful program ${ }^{102}$ and a model for effective RBT implementation. ${ }^{103}$

RBT research in Australia has continued, but with a narrower focus on specific issues such as enhancing deterrence ${ }^{104}$ and maximizing police resources. ${ }^{105}$ Meanwhile, broader reviews

Homel, "Random Breath Testing the Australian Way," supra note 49 at 74.

Watson, Fraine \& Mitchell, supra note 87 at 34-38.

Henstridge, Homel \& Mackay, supra note 83 at 104.

Homel, "Random Stopping Programs in Australia," supra note 67 at 162.

Specifically, Henstridge, Homel \& Mackay recommend that "all states should increase highly visible stationary RBT to a level equivalent to one test per licence holder per year," supra note 83 at 115 . Based on New South Wales data, the authors calculated that increasing the daily testing rate by 1,000 roughly corresponded to a 6 percent decline in total crashes and a 19 percent decline in single vehicle nighttime crashes, ibid at 50. A 2010 Czech study highlights the importance of both high testing levels and mandatory screening. The Czech Republic already had an RBT program when it introduced a binding guideline requiring the police to screen every driver that they stop for any reason. As anticipated, the new law reduced alcohol-related crashes and fatalities. Sucha Matus \& Stastna Lenka, "Effectiveness of Breath Testing of Drivers for Alcohol at Road Checks" (Paper presented at the 19th International Conference on Alcohol, Drugs, and Traffic Safety, 22-26 August 2010, Oslo, Norway) [unpublished]. Henstridge, Homel \& Mackay, ibid at 114-15.

The program in New South Wales achieved an initial 15 percent reduction in fatal crashes, which remained relatively constant for nearly ten years despite significant increases in the population. Ibid at 44. See also Homel, "Drivers Who Drink," supra note 72 at 59-62. However, the sharp declines in serious crashes and single vehicle nighttime crashes were not as stable and only returned to initial high levels through steadily increasing enforcement and publicity. Henstridge, Homel \& Mackay, ibid at 50. Gregory J Casey, "Random Breath Testing — A Successful Policy Recipe" (2006) 7:4 Journal of the Australasian College of Road Safety 29 at 30.

See e.g. Richard Tay, "General and Specific Deterrent Effects of Traffic Enforcement: Do We Have to Catch Offenders to Reduce Crashes?" (2005) 39:2 Journal of Transport Economics and Policy 209; T Prabhakar, SHV Lee \& RFS Job, Factors Involved in the Long Term Benefits of Random Breath Testing in NSW (Sydney: University of Sydney, 1993), online: Australian Government Department of Infrastructure and Transport <http://www.infrastructure.gov.au/road/safety/publications/1993/pdf/RBT NSW.pdf $>$; Barry Watson \& James Freeman, "Perceptions and Experiences of Random Breath Testing in Queensland and the Self-Reported Deterrent Impact on Drunk Driving” (2007) 8:1 Traffic Injury Prevention 11.

See e.g. Susan Hart, Barry Watson \& Richard Tay, "Barriers and Facilitators to the Effective Operation of RBT in Queensland" in Proceedings of the 2003 Road Safety Research, Policing and Education Conference: From Research to Action (Sydney: New South Wales Roads and Traffic Authority, 2003) at 137, online: Road Safety Research, Policing and Education Conference Proceedings <http://www. rsconference.com/pdf/RS030075.pdf>; Barry Watson, James Freeman \& Susan Hart, "A Survey of Operational Police Involved in the Delivery of Random Breath Testing (RBT) in Queensland, Australia" in P Logan, ed, Proceedings of the 18th International Conference on Alcohol, Drugs and Traffic Safety, 
of impaired driving countermeasures have noted the general success of the Australian RBT programs. For example, a 2005 study stated that the Australian RBT programs resulted in "as much as a $24 \%$ reduction in nighttime crashes, especially in metropolitan areas." ${ }^{106}$ A 2009 review reported that RBT reduced total crashes in Australia by 22 percent. ${ }^{107}$

In summary, the Australian experience, especially in New South Wales, ${ }^{108}$ provides compelling evidence of RBT's benefits and insights on how to maximize its effectiveness.

\section{RANDOM BREATH TESTING IN OTHER JURISDICTIONS}

New Zealand replaced its SBT program with RBT, known as "Compulsory Breath Testing" (CBT), in April 1993. ${ }^{109}$ The RBT program has been described as having had "dramatic, sustained effects" that are "unusually high for highway safety measures." 2009 meta-analysis found that the introduction of RBT in New Zealand led to a 14 percent reduction in total crashes. ${ }^{111}$

Similar positive results have been reported by European countries. RBT was largely credited with reducing the percentage of Dutch drivers with BACs over .05 percent from 15 percent in 1970 to 4.5 percent in $2000 .{ }^{112}$ The Finnish RBT program was found to have reduced the number of drinking drivers on the road by 58 percent between 1979 and $1985 .{ }^{113}$ Moreover, a 2008 study involving the capital cities of European Union member states reported that all of the cities with above average decreases in traffic fatalities had RBT programs in place. $^{114}$

In Ireland, RBT was credited with reducing total road fatalities by 19 percent from the preceding 12 months. ${ }^{115}$ There was also a reported 10 percent decrease in traffic related

2007, CD-ROM: (Seattle: ICADTS, 2007)

Joel Grube, "Preventing Alcohol-Related Problems: Public Policy Strategies" in Transportation Research Board, Implementing Impaired Driving Countermeasures: Putting Research into Action (Washington, DC: Transportation Research Board, 2005) 93 at 104, online: Transportation Research Board $<$ http://onlinepubs.trb.org/onlinepubs/circulars/ec072.pdf>. See also WHO, World Report On Road Traffic Injury Prevention: Summary (Geneva: World Health Organization, 2004) at 30, online: WHO $<$ http://www.who.int/violence injury prevention/publications/road traffic/world report/ summary_en_rev.pdf $>$ [WHO, 200̄4].

Alena Erke, Charles Goldenbeld \& Truls Vaa, "The Effects of Drink-Driving Checkpoints on Crashes-A Meta-Analysis" (2009) 41 Accident Analysis \& Prevention 914 at 919 (Table 2).

The Tasmanian RBT program appears to have achieved a similar level of initial success, but this trailed off sharply after the first three months. Moreover, inadequacies in the underlying data make it difficult to draw definitive conclusions about the program's subsequent impact on impaired driving deaths and injuries. Henstridge, Homel \& Mackay, supra note 83 at 65.

Ted Miller, Michael Blewden \& Jia-fang Zhang, "Cost savings from a sustained compulsory breath testing and media campaign in New Zealand" (2004) 36 Accident Analysis \& Prevention 783 at 783. Ibid at 793 .

Erke, Goldenbeld \& Vaa, supra note 107 at 919.

MPM Mathijssen, "Drink Driving Policy and Road Safety in the Netherlands: A Retrospective Analysis" (2005) 41 Transportation Research Part E: Logistics and Transportation Review 395 at 395.

James A Dunbar, Antti Penttila \& Jarmo Pikkarainen, "Drinking and Driving: Success of Random Breath Testing in Finland" (1987) 295:6590 British Medical Journal (Clinical Research Edition) 101 at 102 .

114 European Transport Safety Council, "Road Safety Performance Index" (Brussels: European Transport Safety Council, 2008), online: European Transport Safety Council <http://www.etsc.eu/ documents/ETSC\%20PIN\%20Flash\%2011\%20capital\%20cities.pdf>.

115 Road Safety Authority, Road Safety Strategy 2007-2012 (Ballina, Ireland: Road Safety Authority, 2007) at 7, online: Road Safety Authority $<$ http://www.rsa.ie/Documents/Road\%20safety/RSA_Strategy_ENG s.pdf>. 
hospital admissions in the six months following the introduction of RBT. ${ }^{116}$ Moreover, the deterrent impact of Ireland's RBT program appears to have risen dramatically in the last four years. A 2010 report indicated that total traffic fatalities in Ireland had fallen 42 percent since introducing RBT in $2006 .^{117}$

\section{RANDOM BREATH Testing VERSUS SELECTIVE BREATH TESTING}

The evidence strongly indicates that RBT is more effective than SBT in reducing impaired driving deaths and injuries. ${ }^{118}$ The introduction of RBT in jurisdictions with existing SBT programs has consistently produced favourable results. As noted, Queensland's RBT program resulted in a 35 percent reduction in fatal crashes, whereas the previous SBT program, which operated similarly to Canada's current SBT programs, had resulted in only a 15 percent reduction. ${ }^{119}$ Thus, RBT was more than twice as effective as SBT in reducing fatal crashes. In Western Australia, during a three month period shortly after RBT replaced SBT, ${ }^{120}$ nighttime traffic deaths and injuries decreased 23 percent compared to the same period during the previous year. ${ }^{121}$ In commenting on the shift from SBT to RBT, Homel stated: "[n]othing in the Australian experience encourages the belief that, without the use of full random testing, roadblocks or sobriety checkpoints are capable of delivering a substantial and sustained reduction in alcohol-related casualty crashes." 122 The comparative data from New Zealand and Ireland, both of which operated SBT programs prior to introducing RBT, are equally compelling. ${ }^{123}$

Despite these positive results, some researchers have reported little difference in the efficacy of RBT and SBT programs. However, as the authors of two of the reviews noted, their results must be viewed with caution because they assessed single programs and did not directly compare RBT and SBT checkpoints. ${ }^{124}$ The best data in this regard come from those jurisdictions that changed from an SBT to an RBT program, as would be the case in Canada.

Declan Bedford, "Drink Driving in Ireland" (Paper presented at the Road Safety Authority Conference, Dublin, 13 October 2008) [unpublished], online: Road Safety Authority <http://www.rotr.ie/conference/ presentations/Declan_Bedford_rsa_131008.pdf $>$.

117 Tim O'Brien, "Irish road deaths 'Fall By 42\%," Irish Times (19 May 2010) online: Irish Times $<$ http://www.irishtimes.com/newspaper/breaking/2010/0519/breaking57.html>.

118 This will be important in justifying any Charter violations under section 1, particularly at the "least drastic means" stage of analysis. In order to justify RBT, the government will need to show that no less intrusive measure can achieve the objective of deterring impaired driving. This entails the argument that current SBT programs are insufficient. See Part IV.D.4, Minimum Impairment, below.

119 Henstridge, Homel \& Mackay, supra note 83 at 102 (Table 6.9). The Queensland program was known as "RID" (Reduce Intoxicated Driving). As indicated above, a second Queensland study reported dramatic reductions in alcohol-related fatalities with the introduction of RBT. See Watson, Fraine \& Mitchell, supra note 87.

120 As indicated in supra note 88, Western Australia introduced an intensified random stopping program 18 months before enacting RBT legislation. Although labelled "back-door" or "de facto" RBT, the intensified random stopping program was the equivalent of an SBT program. Homel, "Random Stopping Programs in Australia," supra note 67 at 186.

121 Homel, "Random Stopping Programs in Australia," ibid at 187. As noted, this reduction was achieved even though the police only tested about 50 percent of the drivers who were stopped under the RBT program. RBT's favourable results relative to SBT are explained by its greater deterrent impact. For example, an Australian survey reported that 67 percent of motorists in a jurisdiction operating SBT thought it unlikely that they would be given a breath test in the next month, ibid at 186. Homel, "Random Breath Testing the Australian Way," supra note 49 at 74.

See supra notes 109,111,117 and accompanying text.

Ruth A Shults et al, "Reviews of Evidence Regarding Interventions to Reduce Alcohol-Impaired Driving" (2001) 21(4S) American Journal of Preventive Medicine 66 at 76; Randy W Elder et al, "Effectiveness of Sobriety Checkpoints for Reducing Alcohol-Involved Crashes" (2002) 3:4 Traffic Injury Prevention 266 at 270. 
Unfortunately, none of the reviews examined the additional traffic safety benefits that Queensland, Western Australia, New Zealand, Ireland, and other jurisdictions achieved when they replaced their SBT programs with RBT. Care is also warranted in interpreting these results because the reviews failed to distinguish between the different types of SBT programs.

SBT programs can be divided into two major categories. The first relies on the officer's unaided assessment of the driver and the second involves the use of passive alcohol sensors or similar technology to assist the officers in identifying drinking drivers. Passive alcohol sensors (PAS devices) are small, hand-held devices that are used to detect alcohol in the ambient air around a driver's mouth. The devices are often built into the end of the flashlight, ticket book, or clipboard used by the police. ${ }^{125}$ To be effective, the device must be held within inches of the driver's mouth. In the United States, PAS devices are used by some police departments as a preliminary screening test for the presence of alcohol. ${ }^{126} \mathrm{~A}$ positive result merely provides the police with grounds to demand further testing.

The reviews that reported no significant difference between SBT and RBT appear to include some studies involving SBT checkpoints that used PAS devices. Perhaps the most successful and best known of these was "Checkpoint Tennessee," which was credited with a 20.4 percent reduction in alcohol-related crashes. ${ }^{127}$ Not surprisingly, the effectiveness of SBT checkpoints varies substantially depending upon whether PAS devices are used. ${ }^{128}$ For example, one study found that PAS devices increased the detection rate of drinking drivers at SBT checkpoints by about 50 percent, ${ }^{129}$ and other studies report similar or even greater increases in detection rates. ${ }^{130}$

Since PAS devices are not used in Canadian SBT programs, reference to the effectiveness of the American SBT programs involving sensors can be very misleading. In fact, a recent American study showed that a three-year SBT program in Maryland that did not use PAS devices had no impact whatsoever on alcohol-related crashes and injuries. ${ }^{131} \mathrm{~A}$ further study of the program found that experiencing that type of SBT checkpoint actually decreased drivers' fear of apprehension relative to drivers who merely knew someone who had been stopped. ${ }^{132}$

James C Fell, Christine Compton \& Robert B Voas, "A Note on the Use of Passive Alcohol Sensors during Routine Traffic Stops" (2008) 9:6 Traffic Injury Prevention 534 at 534.

Ibid at 535 .

John H Lacey, Ralph K Jones \& Randall G Smith, Evaluation of Checkpoint Tennessee: Tennessee's Statewide Sobriety Checkpoint Program (Washington: National Highway Traffic Safety Administration, 1999), online: National Highway Traffic Safety Administration <http://www.nhtsa.dot.gov/people/ injury/research/ChekTenn/ChkptTN.html>.

As noted earlier, the vast majority of drinking drivers with BACs below .08 percent and more than half of drivers with BACs above .08 percent go undetected at SBT checkpoints that rely on the officer's unaided assessment. See Part II.C, above.

Jones \& Lund, supra note 54 at 157.

Shults et al, supra note 124 at 76; Ferguson, Wells \& Lund, supra note 54. See Robert B Voas, "A New Look at NHTSA's Evaluation of the 1984 Charlottesville Sobriety Checkpoint Program: Implications for Current Checkpoint Issues" (2008) 9:1 Traffic Injury Prevention 22 at 25, which reported that the introduction in PAS devices in Virginia's SBT checkpoints increased arrests threefold.

Kenneth H Beck, "Lessons Learned From Evaluating Maryland's Anti-Drunk Driving Campaign: Assessing the Evidence for Cognitive, Behavioral, and Public Health Impact" (2009) 10 Health Promotion Practice 370 at 375 .

Kenneth H Beck \& Mary L Moser, "Does the Type of Exposure to a Roadside Sobriety Checkpoint Influence Driver Perceptions Regarding Drunk Driving?" (2006) 30:3 American Journal of Health Behavior 268. 
Finally, "Checkpoint Tennessee" and some of the other American SBT programs measured the traffic safety benefits of moving from an enforcement model that relied almost exclusively on routine patrol activities to high visibility, heavily publicized, intensive SBT. For example, in the Tennessee study, the number of checkpoints increased from 15 in the preceding year to 900 in the program year. ${ }^{133}$ The accompanying mass media campaign included thousands of television and radio public service announcements, print media, mobile billboards, "earned" (independent) media coverage, and public information brochures. ${ }^{134}$ The relevance of these studies to Canada is questionable, given our current widespread use of moderately intensive, well publicized SBT programs. While strengthening Canada's SBT programs would have positive traffic safety benefits, these would not approach those reported in the American studies, where there was a sudden wholesale change in the enforcement approach and its intensity.

All of the above concerns apply equally to a 1998 study which reported that the Australian RBT programs were only slightly more effective than the American SBT programs. ${ }^{135}$ The most recent meta-analysis, ${ }^{136}$ published in 2009, concluded that the Australian RBT programs reduced crashes by 22 percent, while the American SBT programs, some of which presumably used PAS devices, resulted in only a 12 percent reduction. Despite the authors' positive endorsement of RBT, they may have nevertheless underestimated its relative effectiveness. This study is subject to many of the same concerns as the previous studies and the authors acknowledge that their results may have been affected by "outliers." ${ }^{\text {"137 }}$ Moreover, in our view, the study inappropriately characterized several Australian RBT programs as SBT programs on the basis that not all drivers were tested at some RBT checkpoints. ${ }^{138}$

\section{RELATED ISSUES}

\section{PUBLIC SUPPORT}

International experience indicates that RBT enjoys broad public support. In 2002, 98.2 percent of Queensland drivers supported RBT. ${ }^{139}$ Similarly, in a 2006 Irish survey, 87 percent of the participants strongly endorsed RBT. ${ }^{140}$ Moreover, public support appears to increase significantly after RBT is enacted. Prior to the introduction of RBT in New South Wales,

Lacey, Jones \& Smith, supra note 127, Executive Summary.

Ibid, ch 2 .

See Corinne Peek-Asa, "The Effect of Random Alcohol Screening in Reducing Motor Vehicle Crash Injuries"(1999) 16:1S American Journal of Preventive Medicine 57 at 65. Moreover, we would question the author's use of the terms "random screening" and/or "random breath testing" in reference to the Australian RBT and American SBT programs. The stopping of the vehicles in both jurisdictions is random. However, since any demand for a breath sample in the US would have to be based on probable cause, it is inappropriate to use the term "random breath testing" in regard to the American SBT programs. While it could be argued that the American states which use passive alcohol sensors are conducting "random breath screening," this term can readily be misconstrued.

Erke, Goldenbeld \& Vaa, supra note 107.

Ibid at 921.

While their classification may have been necessary for the purposes of the study, it likely resulted in underestimating the efficacy of RBT. Australian police are authorized to conduct RBT and have higher testing rates than police in any other country. Had the Australian programs been classified appropriately, the study would likely have shown a greater difference between the efficacy of SBT and RBT. Ibid at 915.

Watson \& Freeman, supra note 104 at 14.

Alcohol Action Ireland, Alcohol in Ireland: Time for Action - A Survey of Irish Attitudes (Dublin: Alcohol Action Ireland, 2006) at 14, online: Alcohol Action Ireland <http://www.drugsandalcohol.ie/ 6024/1/2907-3757.pdf`. 
public support stood at 63.8 percent. By mid-1983, six months after RBT was introduced, support had increased to 85.3 percent. By 1987, it stood at 97 percent. ${ }^{141}$ In 1974, two years before RBT was introduced, less than 50 percent of those surveyed in Victoria agreed with it. By 1985, support had grown to 75 percent. ${ }^{142}$

There is already broad public support for RBT in Canada, and it appears to be rising. In a 2007 survey, 66 percent of Canadians supported legislation authorizing the police to conduct RBT. ${ }^{143}$ Surveys in the following two years reported virtually identical levels of support. ${ }^{144}$ However, an Ipsos Reid survey conducted in 2010 found that 77 percent of Canadians either "strongly" (46 percent) or "somewhat" (31 percent) supported the introduction of RBT. When informed of RBT's potential to reduce impaired driving deaths, 79 percent agreed that RBT is a "reasonable intrusion on drivers." Seventy-five percent also agreed that the police should be allowed to "randomly require all drivers to give a breath test to help detect impaired driving." "145 These high levels of support for RBT reflect the public's concerns about impaired driving. Ninety-eight percent of respondents considered impaired driving to be a "very important" (81 percent) or "somewhat important" (17 percent) public safety issue, and 87 percent thought that "more could be done to address the problem."146

\section{ThE COST-EFFECTIVENESS OF RANDOM BREATH TESTING}

RBT is generally acknowledged to be the most cost-effective impaired driving countermeasure. In 1990, the estimated annual cost of the New South Wales RBT program, including media, was $\$ 3.5$ million. At that time, the program was conservatively estimated to save 200 lives per year with attendant savings of at least $\$ 140$ million. ${ }^{147}$ Based on these figures, the program had a cost-benefit ratio of 1:40. ${ }^{148}$ Most of these savings were in the area of healthcare and resulted from the reduction in fatalities and serious injuries. ${ }^{149}$ A 2003 European Union study concluded that increasing RBT testing levels to one test per 16

Kearns et al, supra note 83 at 431; Homel, "Random Stopping Programs in Australia," supra note 67 at 177 .

142 Warren Harrison et al, Drink-Driving Enforcement: Issues in Developing Best Practice (Sydney: Austroads, 2003) at 5-6. Other Australian surveys yielded similar results. See Mary Armour, Warren Harrison \& David South, "Random Breath Testing in Victoria" (1987) 86 Alcohol, Drugs and Traffic Safety 433 at 438; Homel, "Random Stopping Programs in Australia," supra note 67 at 75.

Ekos Research Associates Inc, Impaired Driving Survey for Transport Canada/MADD Canada: Final Report (Ottawa: Transport Canada, 2007) at 23, online: Transport Canada $<\mathrm{http} / /$ www.tc.gc.ca/media/ documents/roadsafety/TP14760E-TP14760.pdfs.

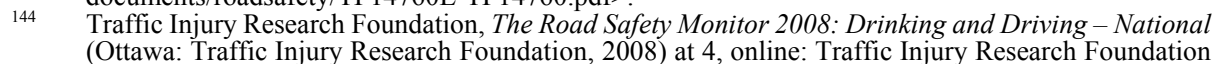
$<$ http://www.tirf.ca/publications/PDF_publications/rsm2008_dd-nat_web.pdf $>$; Vanlaar \& Robertson, supra note 34 at 5 .

Ipsos Reid, Canadian Attitudes Toward Random Breath Testing (RBT) (Oakville: MADD Canada, 2010) at 11, 16-17, online: MADD Canada <http://www.madd.ca/english/research/MADD\%20RBT \%20Survey\%20Results--May\%202010.pdf>. Ibid at $8-9$.

Homel, "Random Breath Testing the Australian Way," supra note 49 at 70.

Another study of this program reported a cost-benefit ratio of only 1:14. Zaal, supra note 70 at 42 , citing HL Camkin, MIE Aust \& KA Webster, Cost-Effectiveness and Priority Ranking of Road Safety Measures (Rosebery, NSW: Traffic Authority of New South Wales, 1988). See also Watson, Fraine \& Mitchell, supra note 87 at 47, who report that Queensland's comprehensive RBT program had a costbenefit ratio of 1:10. 
inhabitants would save between 2,000 and 2,500 lives, and result in a cost-benefit ratio of $1: 36$ or $1: 55$, depending on the model used. ${ }^{150}$

A 2004 World Health Organization (WHO) study reported that each dollar spent on RBT results in an overall cost saving of $\$ 19 .{ }^{151}$ Similarly, a 2004 New Zealand study reported a cost-benefit ratio of $1: 14$ for RBT alone, $1: 19$ for RBT coupled with a media campaign, and 1:26 for RBT in conjunction with both a media campaign and "booze buses" (large, specially equipped vehicles used for on-site evidentiary breath testing, which are typically brightly coloured or otherwise distinctive to attract the attention of all nearby road users). ${ }^{152}$ The study indicated that the additional costs of publicizing and increasing the visibility of RBT programs is greatly outweighed by savings in healthcare and other expenses. In Australia, the costs associated with high visibility RBT were also found to have been partially offset by free publicity in the form of widespread media interest. ${ }^{153}$ Given its demonstrated costeffectiveness, the introduction of comprehensive RBT programs would likely generate very substantial net gains to Canadian society. ${ }^{154}$

\section{DRIVER INCONVENIENCE}

The cost-efficiency of RBT derives in part from its ability to process large numbers of drivers in a relatively short period of time. Once stopped, drivers are typically asked to provide a breath sample without any preliminary discussion, observation, or review of the driver's documents. The driver remains seated in the car, and the breath test itself takes approximately 30 seconds. Thus, a Finnish study reported that drivers undergoing RBT were detained on average for just seconds and that a team of ten officers could test 500 drivers in half an hour. ${ }^{155}$ Similarly, a 2004 New Zealand study indicated that drivers were usually waved through when lineups developed, resulting in a total delay of two minutes or less for most drivers who do not require evidentiary breath testing. ${ }^{156}$

Murray Mackay et al, Cost Effective EU Transport Safety Measures (Brussels: European Transport Safety Council, 2003) at 27, online: European Transport Safety Council <http://www.etsc.eu/ documents/costeff.pdf $>$.

151 Margie Peden et al, eds, World report on road traffic injury prevention (Geneva: World Health Organization, 2004) at 130, online: WHO <http://whqlibdoc.who.int/publications/2004/9241562609. pdf $>$, citing A Eckhardt \& E Seitz, Economic Elaboration of Safety Measures (Berne: Swiss Council for Accident Prevention, 1998). See also Miller, Blewden \& Zhang, supra note 109 at 792.

152 Miller, Blewden \& Zhang, ibid at 783. An analysis of road safety policy in Norway reported that the cost-benefit ratio for RBT was only 1:1.8, and recommended a fivefold increase in testing in Norway. European Road Safety Observatory (ERSO), Promising road safety measures based on cost-benefit analyses (Brussels: ERSO, 2007), online ERSO <http://ec.europa.eu/transport/ road safety/specialist/ knowledge/measures/promising_road_safety_measures_based_on_cost_benefit_analyses/index.htm\#>. See Mary Sheehan, Alcohol Controls and Drink Driving: The Social Context (Canberra: Federal Office of Road Safety, 1994) at 86, online: Australian Government Department of Infrastructure and Transport $<$ http://www.infrastructure.gov.au/roads/safety/publications/1994/pdf/Alc_Social.pdf $>$.

154 See R Soloman et al, "Predicting the Impact of Random Breath Testing on the Social Costs of Crashes, Police Resources, and Driver Inconvenience in Canada" [forthcoming in Crim LQ]. A previous version of this article is available online: MADD Canada <http://madd.ca/english/research/rbt/Predicting $\% 20$ the $\% 20$ Impact $\% 20$ of $\% 20$ RBT.pdf $>$.

155 Dunbar, Penttila \& Pikkarainen, supra note 113 at 101.

156 Miller, Blewden \& Zhang, supra note 109 at 788. Similarly, video footage of a Queensland driver undergoing RBT showed that he was detained for less than two minutes. H Netau, "Random Breath Test - Streets of the Whitsundays" (2008), online: YouTube <http://www.youtube.com/watch? $\mathrm{v}=$ SIviKmdOjBU > . Miller also indicated that drivers subjected to evidentiary breath testing were delayed an average of only five minutes, including waiting time, RBT, and driver/vehicle checks. Although evidentiary testing could be sped up in Canada if conducted at roadside in specially equipped vans, Canadian processing times will, for various reasons, never approximate those in New Zealand, Australia, or most EU countries. For example, section 258(1)(c)(ii) of the Criminal Code requires that two 
Thus, on average, RBT will result in detentions of about the same, or perhaps even shorter duration as the detentions that currently result from the random stops involved in Canadian SBT processing. If officers at SBT checkpoints merely ask drivers a simple question, such as "Where are you coming from?" or "Have you had anything to drink?" before waving them on, then the SBT stops will likely be somewhat shorter or about the same duration as a typical RBT check. However, if officers at SBT checkpoints ask drivers for their licences and other documents, attempt to scrutinize them for signs of alcohol consumption, or closely question them, then the SBT stop will take much longer than a typical RBT check.

\section{Potential Charter Challenges}

As with most changes to police enforcement powers, RBT will invariably be challenged under the Charter. The most probable challenges will be based on section 8 (the right to be free from unreasonable search or seizure), section 9 (the right to be free from arbitrary detention), and section 10(b) (the right to counsel). ${ }^{157}$ As discussed below, strong arguments can be made that RBT does not violate section 8 of the Charter. However, even if RBT does infringe all three Charter provisions, it can be saved under section 1 as being demonstrably justified in a free and democratic society. ${ }^{158}$ The primary purpose of RBT is not to gather evidence for use in a criminal trial. Rather, it is to promote highway safety by screening a large number of drivers and thereby deterring them from driving while impaired by alcohol. Like security screening at airports, borders, courts, and many other public facilities, RBT is intended to discourage risky behaviour and prevent threats to public safety.

\section{A. Section 8: UnReasonable SEARCH AND SEIZURE}

\section{OVERVIEW}

The most rigorous challenges to RBT will likely occur under section 8 , which provides that "[e]veryone has the right to be secure against unreasonable search or seizure." 159 In its pioneering case on section 8 , Hunter $v$ Southam Inc, ${ }^{160}$ the Supreme Court of Canada explained that the rationale for the right is to protect an individual's reasonable expectation of privacy. ${ }^{161}$ It is meant to prevent unreasonable searches before they happen, and thus, is based on a general requirement of prior authorization. Specifically, the court unanimously found that a reasonable search is one that is authorized by a search warrant, obtained in advance from an impartial arbiter, and based on a sworn statement that there are reasonable grounds to believe that an offence has been committed. While warrantless searches and seizures may be upheld in some circumstances, they have to overcome a "presumption of unreasonableness." 162

evidentiary breath tests be conducted and that there be an interval of at least 15 minutes between them. Moreover, under section 10(b) of the Charter, the suspect must be given a reasonable opportunity to contact and consult with legal counsel prior to evidentiary testing.

Supra note 4 .

Ibid.

Ibid.

[1984] 2 SCR 145 [Hunter].

Ibid at 159 .

Ibid at 161 . 
Since RBT is designed to operate randomly and in the absence of any reasonable grounds, it will necessarily operate as a warrantless seizure, ${ }^{163}$ and will need to be justified in accordance with the test that the Supreme Court established in $R v$ Collins. ${ }^{164}$ This test requires that the search or seizure be authorized by law, that the law be reasonable, and that it be carried out in a reasonable manner. Since RBT would be enacted through Criminal Code amendments, it will clearly be "authorized by law." The third element of the Collins test typically addresses how the police conduct the search in a particular case, and thus, cannot be analyzed in the abstract. Therefore the main debate will centre on the reasonableness of the law itself. This in turn will largely depend on whether drivers have a reasonable expectation of privacy with respect to their exhaled breath.

Broadly speaking, there are three degrees of stringency when considering whether section 8 has been violated by a warrantless search or seizure. First, in situations where there is no expectation of privacy, state action will not be considered a search or seizure and section 8 will not be engaged. For example, in $R v$ Patrick, ${ }^{165}$ a majority of the Supreme Court found that the accused did not have a reasonable expectation of privacy with respect to garbage that he had placed at the curb for collection. Therefore, there was no search or seizure within the meaning of section 8 when the police took the garbage and found evidence that the accused was manufacturing ecstasy. ${ }^{166}$ Second, there are situations in which an accused has an expectation of privacy, but it is limited or qualified in some way. While a warrantless search or seizure in these circumstances will come under section 8 scrutiny, it may ultimately be found to be reasonable. For instance, in Thomson Newspapers Ltd $v$ Canada (Director of Investigation and Research, Restrictive Trade Practices Commission), ${ }^{167}$ the Supreme Court found that an order to produce business records for the purposes of an inquiry was a seizure within the meaning of section 8 but that there was a lower expectation of privacy than there would be if, for example, state officials had entered the company's premises. The seizure of the company records was ultimately found to be reasonable. Third, in situations where an accused has a reasonable expectation of privacy, a warrantless search or seizure will be found to violate section 8 and will need to be justified under section 1 of the Charter.

The taking of a breath sample during RBT will almost certainly be found to be a seizure that falls within the meaning of section 8 . As discussed below, the courts have recognized an expectation of privacy with respect to bodily integrity, including the seizure of breath or bodily fluids. However, there is a strong argument that a driver's expectation of privacy is significantly qualified or limited such that a warrantless seizure may still be considered reasonable. The purpose of collecting breath samples through RBT is to promote public safety by ensuring the sobriety of drivers and deterring them from driving while impaired. The breath sample is transitory and will be used for screening purposes only. Driving is

Although nothing crucial turns on this point, it should be noted that RBT is likely to be considered a "seizure," rather than a "search." See $R v$ Dyment, [1988] 2 SCR 417 at 431 [Dyment].

[1987] 1 SCR 265 at 278.

2009 SCC 17, [2009] 1 SCR 579 [Patrick].

See also $R$ v LeBlanc (1981), 64 CCC (2d) 31 (NBCA) [LeBlanc], where police collected the accused's blood from the front seat of a car after a crash. Although LeBlanc occurred before the Charter was enacted, the Supreme Court of Canada explained in a post-Charter case that LeBlanc had "abandoned" his blood, and thus no longer had a reasonable expectation of privacy with respect to it. The blood was accordingly "gathered" rather than "seized," and section 8 would not have been implicated. Dyment, supra note 163 at 435 . 
already a heavily regulated activity so the taking of a breath sample for screening purposes should be seen as a relatively minor intrusion on privacy and a logical extension of the existing obligation to provide evidence of licencing, vehicle ownership, insurance, and the mechanical fitness of the vehicle. Much like other screening procedures, RBT should be analyzed in terms of its primary purpose as a screening tool designed to protect public safety. In this context, it should be considered a reasonable search.

However, even if RBT is considered to be an unreasonable search and seizure, it is justifiable under section 1 in light of the public safety risks posed by impaired driving. While it may initially seem incongruous to conclude that a search can be "unreasonable" but still "justifiable," this is consistent with the accepted analysis of the interplay between sections 8 and 1. Canada's leading constitutional scholar, Professor Peter Hogg, has stated that the test for a "reasonable search" under section 8 is narrower than the test for a "reasonable limit" under section 1, and that an unreasonable search may well be justified in light of the government objectives. ${ }^{168}$ For the sake of convenience, all of the section 1 arguments are addressed after the analysis of the rights in sections 8, 9, and 10(b).

\section{RANDOM BREATH TESTING AND THE EXPECTATION OF PRIVACY}

To what extent does a driver have an expectation of privacy in his or her exhaled breath? In $R v$ Edwards, ${ }^{169}$ a majority of the Supreme Court explained that the determination of whether there is a reasonable expectation of privacy requires consideration of "the totality of the circumstances," and that the expectation has both subjective and objective components. ${ }^{170}$ That is, did the accused him or herself have an expectation of privacy and was that expectation objectively reasonable? Further, in Patrick, the Supreme Court warned that a person's expectation of privacy should not be diminished by the fact that society has become accustomed to state intrusions. As Justice Binnie explained, "[a] government that increases its snooping on the lives of citizens, and thereby makes them suspicious and reduces their expectation of privacy, will not thereby succeed in unilaterally reducing their constitutional entitlement to privacy protection." 171 Thus, as Justice Binnie held in $R v$ Tessling, ${ }^{172}$ the expectation of privacy is not just a descriptive standard, but a normative one. $^{173}$

In examining the "totality of the circumstances" involved in seizing a breath sample under RBT, several factors are of particular importance. First, the courts have typically accorded

Peter W Hogg, Constitutional Law of Canada, looseleaf (consulted on 31 March 2011), 5th ed (Toronto: Thomson Reuters Canada, 2007), ch 38 at 47.

[1996] 1 SCR 128 at 145-46, Justice Cory.

See Jane Bailey, "Framed by Section 8: Constitutional Protection of Privacy in Canada" (2008) 50

Canadian Journal of Criminology \& Criminal Justice 279 at 286.

Patrick, supra note 165 at para 14 .

2004 SCC 67, [2004] 3 SCR 432 at para 42 [Tessling].

While we do not disagree that section 8 should reflect a normative standard, we question whether the courts are necessarily in the best position to evaluate social norms. In our experience, the Canadian courts have been excessively squeamish about the taking of bodily samples. On a broader level, we question whether the courts' views on the intrusiveness of traffic safety enforcement necessarily reflect the views and values of the Canadian public, who generally support enhanced testing. See Erika Chamberlain \& Robert Solomon, "Enforcing Impaired Driving Laws Against Hospitalized Drivers: The Intersection of Healthcare, Patient Confidentiality, and Law Enforcement"(2010) 29 Windsor Rev Legal Soc Issues 45; and Part III.C.1, above. 
a high degree of privacy to bodily integrity and bodily samples. In the leading case of $R v$ Stillman, Justice Cory observed, "[i]t has often been clearly and forcefully expressed that state interference with a person's bodily integrity is a breach of a person's privacy and an affront to human dignity. The invasive nature of body searches demands higher standards of justification." 174 In impaired driving cases, the Canadian courts have found a reasonable expectation of privacy with respect to breath ${ }^{175}$ and blood ${ }^{176}$ samples, where those samples have been used for the purposes of criminal prosecution. ${ }^{177}$

Balancing against this, however, is the fact that providing a breath sample on an ASD is minimally intrusive. Placed on the spectrum of bodily intrusions, breath samples are much less intrusive than providing other bodily fluids (such as urine or blood), pat-down and strip searches, searches of body cavities, and so-called "bedpan vigils." ${ }^{\prime 18}$ In fact, providing a breath sample seems less intrusive than having hair samples or buccal swabs taken for DNA testing, which were found not to violate section 8 in $R v S A B .{ }^{179}$ While that case admittedly examined DNA samples seized under a special warrant for forensic analysis, ${ }^{180}$ it does suggest that the courts are becoming less prudish about the taking of bodily samples than they were in the 1980s and 90s, when for example, the Ontario Court of Appeal referred to the taking of a blood sample as "an interference of a very intrusive nature,"181 and somewhat melodramatically condemned the taking of a breath sample as the seizure of "the very breath one breathes." 182 By contrast, Justice Arbour explained in $S A B$ that the process of DNA testing is not necessarily intrusive:

[U]nder a properly issued DNA warrant, the degree of offence to the physical integrity of the person is relatively modest. A buccal swab is quick and not terribly intrusive. Blood samples are obtained by pricking the surface of the skin - a procedure that is, as conceded by the appellant, not particularly invasive in the physical sense. With the exception of pubic hair, the plucking of hairs should not be a particularly serious affront to privacy or dignity. ${ }^{183}$

We submit the approach in $S A B$ provides a more realistic assessment of the level of physical intrusiveness involved in taking many bodily samples.

Extending this reasoning to RBT, the capture of a driver's exhaled breath seems minimally intrusive. The sample takes only seconds to provide and does not involve pain or discomfort. ${ }^{184}$ There is no intrusion into the driver's body, nor an exposure of any body parts

[1997] 1 SCR 607 at para 42.

See e.g. $R v$ Wills (1992), 70 CCC (3d) 529 (Ont CA) [Wills]; $R v$ Haas (2005), 76 OR (3d) 737 (CA). See e.g. Dyment, supra note 163; $R$ v Pohoretsky, [1987] 1 SCR 945; $R$ v Colarusso, [1994] 1 SCR 20. There has been some suggestion that the reasonable expectation of privacy is lower with respect to roadside (i.e. non-evidentiary) breath tests. See Justice L'Heureux-Dubé's reasons in $R v$ Bernshaw, [1995] 1 SCR 254 at 307-308.

See $R v$ Monney, [1999] 1 SCR 652 at 681-82 [Monney], where the use of a "drug loo" facility at an airport was found to be a reasonable search. While the Court found that the compelled production of a bowel movement was an embarrassing process, it did not interfere with bodily integrity (at 681-82). 2003 SCC 60, [2003] 2 SCR 678 [SAB].

Criminal Code, supra note 41, ss 487.04-487.09.

$R v$ Pavel (1989), 53 CCC (3d) 296 (Ont CA) at 310. See also $R v$ Hanet (BD) (1996), 182 AR 30 (Prov

$\mathrm{Ct})$ at para 20.

Wills, supra note 175 at 540.

$S A B$, supra note 179 at para 44 [references omitted].

See the considerations listed by the court in $R v F(P R)$ (2001), 57 OR (3d) 475 (CA) at para 17, summarizing $R v$ Briggs (2001), 55 OR (3d) 417 (CA). 
that are normally concealed. Indeed, some of the arguments that have been made in support of fingerprinting could be made with greater force in support of breath testing on ASDs. For instance, in $R v$ Beare; $R v$ Higgins, ${ }^{185}$ Justice La Forest explained, "[w]hile some may find [fingerprinting] distasteful, it is insubstantial, of very short duration, and leaves no lasting impression. There is no penetration into the body and no substance is removed from it."186 Further, unlike fingerprints, which provide a lasting record and may tie an individual to other crimes, ${ }^{187}$ the results of a breath test on an ASD are transitory and do not implicate a driver in any other offence.

In addition, the Supreme Court of Canada has also gauged the intrusiveness of a search by the information it reveals about an individual. In $S A B$, the court stressed that the Criminal Code's DNA warrant provisions only provide for the use of "non-coding" DNA, such as a DNA sample that can be compared to an existing sample, but that "does not reveal any medical, physical or mental characteristics" about the individual. ${ }^{188}$ Thus, it reveals a minimal amount of personal information. Similarly, in Tessling, the Court found that the use of thermal imaging to detect heat patterns emanating from the accused's home did not involve a reasonable expectation of privacy because it revealed no personal information or intimate details of the occupants' lifestyle. ${ }^{189}$ Accordingly, it did not even qualify as a search under section 8. Based on this criterion of intrusiveness, RBT is relatively innocuous. No personal information about the driver is gathered apart from his or her BAC. Given that it is illegal to drive while impaired by alcohol, there should be a limited expectation of privacy regarding such information.

Moreover, several of the cases that discuss the reasonable expectation of privacy in terms of bodily integrity focus on the humiliation and loss of dignity involved in bodily searches. For example, there is considerable stigma attached to being segregated at an airport for a strip search, and it is undoubtedly humiliating to be the subject of a bedpan vigil. Yet, both of these procedures have been upheld as reasonable searches under section 8 of the Charter. ${ }^{190}$ In contrast, the provision of a breath sample during RBT is neither stigmatizing nor humiliating because every driver passing through a checkpoint is tested. The routine testing of all drivers means that no one need feel singled out or under particular suspicion when asked to provide a breath sample. Drivers can remain in their vehicles throughout the process, so there is no public exhibition of the testing process. Comparably, in Simmons, the Supreme Court commented on the routine inspection of baggage and pat-down searches at airports: "No stigma is attached to being one of the thousands of travellers who are daily routinely checked in that manner upon entry to Canada and no constitutional issues are

[1988] 2 SCR 387.

Ibid at 413.

See $R v$ Dore (2002), 166 CCC (3d) 225 (Ont CA), where the Court stressed that an individual who has been cleared of criminal wrongdoing has a renewed expectation of privacy with respect to his or her fingerprints and could request their return or destruction. However, it is not unconstitutional for the state to retain fingerprint records in the absence of such a request.

Supra note 179 at para 49.

Supra note 172 at para 62. See also $R v$ Plant, [1993] 3 SCR 281 [Plant], where similar reasoning was used to find that a search of the accused's records of electricity consumption was not unreasonable under section 8. See generally Susanne Boucher \& Kenneth Landa, Understanding Section 8: Search, Seizure, and the Canadian Constitution (Toronto: Irwin Law, 2005), ch 3 at 26ff.

$R v$ Simmons, [1988] 2 SCR 495 at 529 [Simmons]; Monney, supra note 178. 
raised." ${ }^{191}$ The court also explained that because of state security interests and the diminished expectation of privacy at border crossings, such routine border inspections neither violated section 8 nor constituted "detentions" within the meaning of the Charter. ${ }^{192}$

Indeed, it is instructive to compare RBT to the screening procedures used at airports and many government buildings, where every passenger or entrant is required to pass through metal detectors and have his or her baggage and/or person searched. In 2008, over 109 million passengers were subject to random screening and search procedures at Canada's airports. An additional 67 million travellers were subject to screening and search at Canada's borders. ${ }^{193}$ Moreover, in recent years, airport searches in particular have become far more intensive. It is not uncommon for passengers to be required to remove their shoes and belts, swabbed for explosives' residue, scanned for weapons and explosives concealed under their clothing, and subject to thorough pat-down searches (which involve touching the passenger's neck, arms, legs, chest, hips, and buttocks through his or her clothes). Yet, as Hogg has expressed, "[ $\mathrm{t}]$ he concerns about safety that prompt these procedures are well understood by travellers, and so far as I know they have never been challenged."194

While the Court in Simmons reasoned that more intrusive searches were justifiable at borders because of state security interests, ${ }^{195}$ we would question whether these interests are fundamentally different from the state interest in road safety, given that driving is a licenced, heavily regulated activity. Canada is not facing armed insurrection or invasion, or the overthrow of its political or economic systems. To put it bluntly, many more people are killed in alcohol-related crashes every year than by terrorist attacks on airplanes or on Canada's domestic soil. Thus, while it is politically easy to justify invasive searches in the name of national security, we are not convinced that sharp distinctions can be drawn in Canada between random searches at the border and random breath testing of drivers on our roads. Driving, ${ }^{196}$ like air travel and other regulated activities, ${ }^{197}$ involves a reduced expectation of privacy and is thus subject to random inspection by law enforcement. Furthermore, we would venture to say that for many people, it is a much greater intrusion on privacy to have one's purse, briefcase, and luggage searched, and much more humiliating to be patted down in public or strip searched in private at a busy public airport, than it is to provide a breath sample while sitting in one's car for two minutes at roadside during an RBT checkpoint. Compared to the warrantless strip search that the Supreme Court of Canada upheld in Simmons, RBT is comparatively inoffensive and provides far greater public safety benefits.

The Court indicated that border searches involve a lower expectation of privacy than other searches. Thus, while a pat-down search might be unreasonable elsewhere, it would be reasonable at the border. The Court based this special treatment of border searches on the state's interests in security and in preventing entry of contraband. Simmons, ibid, 517. Ibid at 528-29.

See Minister of Public Works and Government Services, Transportation in Canada 2008: An Overview (Ottawa: Minister of Public Works and Government Services, 2008) at 18, online: Transport Canada $<$ http://www.tc.gc.ca/media/documents/policy/overview_1.pdf >; Canada Border Services Agency, "CBSA National Statistics: Trade and Traveller Statistics," online: Canada Border Services Agency $<$ http://www.cbsa-asfc.gc.ca/agency-agence/stats/trade-echange-eng.html $>$. Supra note 168, ch 48 at 37.

Simmons, supra note 190 at 528.

See Part II.C, above.

See e.g. Re Belgoma Transportation Ltd v Director of Employment Standards (1985), 51 OR (2d) 509 (CA) (employment standards); $R v$ Bichel (1986), 33 DLR (4th) 254 (BCCA) (building inspection); $R$ $v$ McKinlay Transport Ltd, [1990] 1 SCR 627 (income tax). 
Concerns about public safety have also been used to justify the security screening that occurs at courthouses. ${ }^{198}$ In $R v$ Campanella,${ }^{199}$ the Ontario Court of Appeal found that the government had a legitimate interest in screening courthouse entrants for weapons in order to provide a safe and secure courtroom environment. The Court reached this conclusion based on primarily anecdotal evidence, stating, "[i]t is notorious that, unfortunately, there have been serious incidents of violence in the courthouses of this province by the use of weapons that have been brought into the courthouse." ${ }^{200}$ The Court also found it important that all entrants were screened, thereby removing any element of discretion that might make the search seem discriminatory or arbitrary. In addition, the Court noted that the primary purpose of the search was not the enforcement of the criminal law, so the standard of reasonableness was more lenient. This was true even though the accused in question had been charged with drug possession after the courtroom screening uncovered a bag of marijuana in her purse. Finally, the Court stressed that all courtroom entrants were "beneficiaries" of the screening process, since it ensured a higher degree of safety for everyone. $^{201}$

Although the reasoning in Campanella has rarely been extended to other situations, ${ }^{202}$ the Court's arguments with respect to courtroom screening can be made with far greater force in regard to RBT. The state has a legitimate and substantial interest in traffic safety, and the risks posed by impaired drivers are much greater and better documented than those posed by relatively rare violent courtroom entrants. Since all drivers at sobriety checkpoints will be subject to RBT, there can be no allegations of discrimination. Further, while RBT may lead to some drivers being subjected to evidentiary breath testing and potential criminal charges, this is not the primary purpose of the procedure. Moreover, all drivers, passengers, and pedestrians will benefit from RBT because it will significantly reduce the incidence of impaired driving on Canada's roads.

As indicated, a driver's expectation of privacy needs to be considered in light of the fact that driving is a licenced and heavily regulated activity. In this vein, "[d]rivers expect to be stopped and questioned by the police concerning matters relating to the operation of their vehicles. ${ }^{, 203}$ In $R v$ Hufsky, ${ }^{204}$ the Supreme Court found that there is no violation of section 8 when drivers are asked to provide licencing and insurance documents to police for inspection. The Court explained that there is no expectation of privacy "where a person is required to produce a licence or permit or other documentary evidence of a status or

See $R v$ Lindsay (DK) (2004), 187 Man R (2d) 236 (CA).

(2005), 75 OR (3d) 342 (CA) [Campanella].

The Court did not cite any specific incidents or statistics. Ibid at para 18.

Ibid at paras 19-24.

Most of the cases following Campanella also deal with courthouse screening procedures. See e.g. $R v$ Stewart (2005), 78 OR (3d) 744 (Sup Ct); $R$ v Riley, [2008] OJ no 2116 (SCJ) (QL). Campanella was also cited by Justice Deschamps (dissenting) in $R v A M, 2008$ SCC 19, [2008] 1 SCR 569, where she argued that the inspection of a student's backpack by a sniffer dog at school did not constitute a search under section 8 because there was no reasonable expectation of privacy. She reasoned that, analogous to the courthouse search in Campanella, all students and staff were the beneficiaries of a drug-free environment at school.

$R v$ Smith (1996), 28 OR (3d) 75 (CA) at 94. See also $R v$ Pontes, [1995] 3 SCR 44 at 99: "There is no fundamental right to drive a motor vehicle.... It is a privilege, a privilege which, sadly, is often abused with tragic repercussions. A legislature can provide for consequences which are to attach when this privilege is abused and stipulate standards of behavior for continued licensing."

[1988] 1 SCR 621 [Hufsky]. 
compliance with some legal requirement that is a lawful condition of the exercise of a right or privilege." 205

While we acknowledge that drivers have a greater expectation of privacy with respect to bodily samples than their licencing and insurance documents, it is still a qualified expectation of privacy. Maintaining a BAC below .08 percent is, like having a licence, a condition of one's driving privilege. By logical extension to Hufsky, there is a limited expectation of privacy with respect to RBT. While an individual has an expectation of privacy in a driver's licence when in a café or walking down the street, this expectation disappears when the individual is required to prove compliance with conditions voluntarily undertaken by engaging in a licenced activity. As stated by the Supreme Court in $R v$ Wise:

\footnotetext{
For the safety of all, it is essential that drivers be tested before receiving their licence; that RIDE [Reduce Impaired Driving Everywhere] programs be instituted to discourage the drinking driver; that the speed of vehicles be supervised and that the mechanical fitness of vehicles be inspected. These inspections and tests and this supervision do not constitute unreasonable breaches of basic civil liberties. Rather, they are common sense rules that exist for the protection of society as a whole... Without them, motor vehicles inevitably become instruments of crippling injury, death and destruction.
}

Society then requires and expects protection from drunken drivers, speeding drivers and dangerous drivers.... All this is set out to emphasize that, although there remains an expectation of privacy in automobile travel, it is markedly decreased relative to the expectation of privacy in one's home or office. ${ }^{206}$

Similarly, the expectation of privacy an individual has in his or her own exhaled breath will be limited when the individual engages in a licenced activity that involves considerable risk and requires a degree of sobriety.

Finally, when examining the "totality of the circumstances" surrounding an individual's expectation of privacy, it must be remembered that breath samples taken during RBT checkpoints will be used for screening purposes only, and not as evidence in criminal proceedings. The breath sample is transitory, used only once, and does not give rise to any lasting record. Objectively speaking, most drivers will not consider providing a breath sample to be an offensive intrusion of bodily integrity. The fact that Canadians ${ }^{207}$ and citizens of many comparable democracies ${ }^{208}$ are highly supportive of RBT programs suggests that reasonable drivers have a low expectation of privacy with respect to their exhaled breath.

\section{BALANCING THE GOVERNMENT INTEREST AGAINST THE INDIVIDUAL INTEREST IN PRIVACY}

The courts will most likely find that drivers have at least some expectation of privacy with respect to their breath. To determine whether RBT is reasonable, the analysis will turn on whether a driver's privacy interest is outweighed by the government interest in deterring impaired driving through RBT. The balancing test was explained by Justice Dickson in 
Hunter: "[A]n assessment must be made as to whether in a particular situation the public's interest in being left alone by government must give way to the government's interest in intruding on the individual's privacy in order to advance its goals, notably those of law enforcement." ${ }^{209}$ In our view, any intrusion into drivers' privacy interests is far outweighed by the government interest in screening for impaired drivers and deterring driving after drinking. Accordingly, the seizure that occurs during RBT is reasonable, and does not violate section 8 .

The Canadian courts have repeatedly found that there is a significant government interest in preventing impaired driving. For example, in $R v$ Saunders, the Ontario Court of Appeal commented: "It is hard to imagine a greater danger to society than the drinking driver. There can be little doubt that this crime causes more deaths, serious injuries, heartaches and social problems than almost any other crime. ${ }^{, 210}$ Further, as indicated in Part II.C, above, current police practices fail to detect the majority of drinking drivers stopped at sobriety checkpoints, even those with BACs above .08 percent. When there is a low risk of detection, the deterrent effect of our impaired driving laws is minimized. This helps to explain why millions of Canadians continue to drink and drive, with predictably tragic consequences. The government interest in improving impaired driving deterrence is therefore substantial.

As the international experience demonstrates, RBT is highly effective in improving detection rates and thereby increasing general deterrence. When drivers expect to be tested on a routine basis, they are less likely to drive after drinking. Again, this is similar to the effects of security screening at airports, borders, courts, and other government facilities. Thus, for example, airline passengers expect to pass through metal detectors, to have their hand luggage searched and, increasingly, to be subject to more thorough secondary screening. As this probability increases, fewer passengers attempt to bring weapons or other hazardous objects onto planes. ${ }^{211}$ The screening process has a deterrent effect and prevents the public from being put at risk.

Given the compelling state interest in keeping impaired drivers off the roads, the highly regulated nature of driving, the qualified expectation of privacy involved, and the minimal and transitory intrusiveness of the RBT procedure, a very strong argument can be made that RBT involves a reasonable search and does not violate section 8 . Nevertheless, even if RBT is found to violate section 8 , it can be justified under section 1, as discussed in Part IV.D, below.

211 See Susan E Martonosi \& Arnold Barnett, "How Effective Is Security Screening of Airline Passengers?" (2006) 36:6 Interfaces 545. Not surprisingly, would-be terrorists who successfully pass through airline security are more likely to attempt to bring prohibited items on board in the future. Similarly, impaired drivers who successfully evade detection at SBT checkpoints have a reduced expectation of subsequent detection. See Beck \& Moser, supra note 51. 


\section{B. SECTION 9: ARBITRARY DETENTION}

Section 9 of the Charter provides, "Everyone has the right not to be arbitrarily detained or imprisoned." 212 The elements and parameters of this right are relatively well-established and uncontroversial. It must be determined whether the subject was detained, and whether that detention was arbitrary. ${ }^{213}$ The Supreme Court recently reviewed the principles governing section 9 in $R v$ Grant ${ }^{214}$ Chief Justice McLachlin and Justice Charron, for the majority, indicated that the purpose of section 9 is to "protect individual liberty from unjustified state interference." ${ }^{215}$ Section 9 protects not only against direct interferences with physical liberty, but also against interferences with "mental liberty" through the use of coercion or psychological pressure. ${ }^{216}$ Citing the seminal decision of $R v$ Therens, ${ }^{217}$ the majority in Grant indicated that a person is detained whenever he or she "submits or acquiesces in the deprivation of liberty and reasonably believes that the choice to do otherwise does not exist." ${ }^{218}$ The majority further indicated that roadside breath testing is a classic example of such a detention, because there are legal penalties for failing to comply with an officer's request. ${ }^{219}$ Given these consequences, a driver does not truly have a free choice about whether to provide a breath sample, and will be considered to be detained within the meaning of the Charter.

The Supreme Court considered the application of section 9 to random traffic stops in Hufsky. While the stop was found to infringe section 9, it was upheld as a reasonable limit under section 1. The accused in Hufsky was stopped by police in a random spot check, the purposes of which were to inspect licencing and insurance documents, ensure the mechanical fitness of vehicles, and assess driver sobriety. There were no particular criteria by which vehicles were selected to be stopped; this was left to the officer's discretion. Although Justice Le Dain, for the Court, conceded that the random stop was "of relatively brief duration," he found that it nevertheless constituted a detention within the meaning of the Charter. The key factor was that "the police officer assumed control over the movement of the [accused] by a demand or direction that might have significant legal consequence, and there was penal liability for refusal to comply with the demand." ${ }^{, 20}$ Because the relevant highway traffic legislation made it an offence to refuse to stop when directed by a police officer, the accused had no real choice but to stop. This element of coercion was sufficient to make the stop a detention under section 9.

With respect to the second element of section 9, Justice Le Dain found that the stop was arbitrary because, although authorized by statute and for lawful purposes, "there were no criteria for the selection of the drivers to be stopped and subjected to the spot check

Supra note 4, s 9.

See generally $R v$ Mann, 2004 SCC 52, [2004] 3 SCR 59 at para 19, where the majority noted that section 9 is typically implicated when there is some physical or psychological restraint of the subject, and not simply when someone is "delayed" or "kept waiting."

2009 SCC 32, [2009] 2 SCR 353 [Grant].

Ibid at para 20.

Ibid.

[1985] 1 SCR 613 [Therens].

Grant, supra note 214 at para 25, citing Therens, ibid at 644.

Grant, ibid at para 30.

Justice Le Dain was referring to the penalty in the Ontario Highway Traffic Act (then RSO 1980, c 198, s $189 \mathrm{a}(2))$ for failing to comply with an officer's demand to stop a vehicle. Hufsky, supra note 204 at 632. 
procedure. The selection was in the absolute discretion of the police officer."221 Justice Le Dain stated that a law creating a discretionary power would be arbitrary "if there are no criteria, express or implied, which govern its exercise." 222 Thus, according to Hufsky, it would appear that stopping drivers at random spot checks amounts to an arbitrary detention, contrary to section 9. Relying on Hufsky, the Supreme Court found that random stops during routine patrol activities, as opposed to during organized spot checks, also violate the prohibition on arbitrary detention. ${ }^{223}$

Because both random stops and roadside breath testing have been found to be arbitrary detentions, there is little doubt that RBT, which is an extension of those detentions, will also be found to contravene section 9. It does not matter that any additional period of detention created by RBT will be relatively brief or that it will be only a minor inconvenience to the vast majority of drivers. Moreover, it does not matter that RBT will be authorized by legislation, because the courts will likely find that the legislation itself is arbitrary. ${ }^{224}$ The determinative factors are that police will assume control of vehicles, that there will be no individualized criteria for selecting the vehicles to be stopped or the drivers to be tested, and that there will be legal consequences for drivers who fail to comply. This is sufficient to constitute arbitrary detention.

It could be argued that RBT, while arbitrary, will be somewhat less capricious than the stops involved in Hufsky because every driver passing through an RBT checkpoint will be subject to a breath test. This removes the element of subjectivity or discretion and, with it, any suggestion that certain classes of drivers are being unfairly targeted or profiled by police. ${ }^{225}$ Nevertheless, as explained above, RBT legislation should be drafted so that breath screening tests can be demanded at both fixed checkpoints and during routine patrol activities. ${ }^{226}$ In either case, effective RBT legislation will likely be found to violate section 9 and will need to be justified under section 1, as discussed below.

\section{SECTION 10(B): Right TO COUNSEL}

The right in section 10(b) of the Charter to retain and instruct counsel is triggered when a person is detained. The meaning of "detention" is the same for this section as it is for section 9.227 Thus, as discussed above, a driver who is stopped for the purposes of RBT will be "detained" within the meaning of the Charter and will have the right to retain and instruct counsel without delay. Similarly, the Canadian courts have unanimously held that the right to counsel is triggered when a driver is directed to provide a breath sample on an ASD, ${ }^{228}$ to

Hufsky, ibid at 633.

Ibid. See also Charkaoui v Canada (Citizenship and Immigration), 2007 SCC 9, [2007] 1 SCR 350 at para 89, citing Peter W Hogg, Constitutional Law of Canada, looseleaf (consulted on 12 May 2011), vol 2 (Scarborough: Thomson Canada, 1997), ch 46 at 5, where the Court explained that a detention will not be arbitrary if it is guided by standards that are rationally related to the purpose of the detention. $R v$ Ladouceur, [1990] 1 SCR 1257 at 1277 [Ladouceur].

See Grant, supra note 214 at para 54.

The allegation that RBT will be used as a means of "profiling" was made in Janice Tibbetts \& Kenyon Wallace, "Tories Revive Random Roadside Breath Test" The National Post (9 March 2010), online: $<$ http://www.vive/ecanada.ca/article/235930771-tories-revive-random-roadside-breath-test>.

See supra notes 69-70 and accompanying text.

Hufsky, supra note 204 at 632.

Seo, supra note 210; $R$ v Thomsen, [1988] 1 SCR 640 [Thomsen]. 
answer police questions, ${ }^{229}$ or to submit to physical coordination testing ${ }^{230}$ for the purposes of determining impairment. Requiring drivers to submit to questioning and these tests without an opportunity to consult counsel infringes section 10(b). However, the Supreme Court of Canada has upheld these infringements of section 10(b) under section 1 of the Charter. As discussed below, RBT should also be upheld under section 1.

\section{SECTION 1: WHETHER ANY INFRINGEMENTS ARE JUSTIFIED}

In all likelihood, RBT will be found to violate at least sections 9 and 10(b) of the Charter. As a result, it will need to be justified under section 1 as being a reasonable limit "prescribed by law [that] can be demonstrably justified in a free and democratic society." ${ }^{231}$ We believe that, like other impaired driving countermeasures, RBT will be upheld. This requires analysis of the five elements set out in $R v$ Oakes: (i) Is the infringement prescribed by law? (ii) Does it respond to a pressing and substantial legislative objective? (iii) Is the measure rationally connected to the objective? (iv) Does it infringe Charter rights as little as possible? (v) Do its positive effects outweigh its deleterious effects? ${ }^{232}$ As in most section 1 cases, the determinative consideration will be the minimum impairment test or whether the right is infringed as little as possible.

\section{PRESCRIBED BY LAW}

The first requirement under section 1 is that the impugned action be "prescribed by law." This requirement is meant to ensure that any limitations on Charter rights are accessible to the public and that they are sufficiently precise that individuals can conduct themselves accordingly. ${ }^{233}$ Perhaps more importantly, it ensures that police or other authorities are not acting arbitrarily or abusively, and that any infringement of Charter rights is legally authorized. Given that RBT will be enacted through legislation, it will meet this test. Indeed, this is one reason why it is important to provide statutory authority for RBT, rather than promoting it through police practice alone. It is also important that the legislation provide authority for the stop, detention, and testing to be completed without the driver having the opportunity to consult counsel. While this limitation will sometimes be implied by the legislation, ${ }^{234}$ it is more prudent to make this authority explicit. ${ }^{235}$

\footnotetext{
229 See Orbanski, supra note 39.

$230 \quad$ Ibid; Saunders, supra note 210.

231 Supra note 4, s 1.

232 [1986] 1 SCR 103 [Oakes].

233 Greater Vancouver Transportation Authority v Canadian Federation of Students - British Columbia Component, 2009 SCC 31, [2009] 2 SCR 295 at para 50. See Hogg, supra note 168, ch 38 at 12.

For example, in Therens, supra note 217, the authority to demand an ASD test without allowing a driver to consult counsel was implied by the requirement in section 254(2) of the Criminal Code that the sample be provided "forthwith," a word which connotes urgency.

235 In Orbanski, supra note 39, only the majority found that the limitation on the right to counsel prior to physical coordination testing was implied by the relevant highway traffic legislation. The dissenting justices rejected this argument and found that the limitation on the right to counsel was not prescribed by law.
} 


\section{PRESSING AND SubSTANTIAL CONCERN}

The Supreme Court of Canada has routinely recognized that impaired driving is a pressing and substantial concern. ${ }^{236}$ In Ladouceur, for example, Justice Sopinka wrote regarding the police power to stop vehicles at random:

\footnotetext{
There cannot be any serious doubt that the legislation in question deals with a pressing and substantial concern. The statistics paint a depressing picture of the killing and maiming that results from the operation of motor vehicles on the streets and highways of the nation. The evidence filed vividly demonstrates the validity of the pressing and substantial nature of the concern. ${ }^{237}$
}

Although 20 years have passed since Ladouceur, impaired driving is still a pressing and substantial concern. In the more recent case of Orbanski, Justice Charron stated summarily: "There is no question that reducing the carnage caused by impaired driving continues to be a compelling and worthwhile government objective."238

As noted earlier, impairment related crashes remain the leading criminal cause of death in Canada, ${ }^{239}$ with costs estimated at $\$ 21.62$ billion per year. Moreover, while there has been improvement since the record high levels of the early 1980s, millions of Canadians continue to drink and drive. ${ }^{240}$ Canada's current approach has fallen far short of its stated targets for reducing alcohol-related crashes, and the number of deaths and injuries have fluctuated little since $2000 .^{241}$ It is clear that additional measures are necessary to deter impaired driving and reduce the carnage on Canadian roads. Thus, RBT should easily satisfy this part of the Oakes test.

\section{RATIONAL CONNECTION}

RBT should also satisfy the next requirement of the Oakes test, which is that the law in question be rationally connected to the government objective. As indicated, RBT has been introduced in numerous countries around the world as a means of deterring impaired driving and has consistently been shown to reduce fatal and serious injury crashes and the incidence of impaired driving. A New Zealand study recently referred to it as the "best proven defense against drunk-driving." 242

In Hufsky, the Supreme Court recognized the difficulties of detecting impaired drivers through routine patrols alone and the importance of increasing the perceived risk of detection in order to increase the existing law's deterrent effects. ${ }^{243}$ The Court stated that random stopping was "calculated to increase the perceived risk of the detection of impairment 
because it affords a police officer a closer opportunity for observation of a driver's condition. It is seen as a means of making mandatory roadside breath testing more effective." ${ }^{244}$

However, as Canada's traffic safety record shows, even the sobriety checkpoints that were upheld in Hufsky have had an insufficient deterrent effect. This is largely because the vast majority of drinking drivers go undetected under the existing practices and legal criteria for testing. ${ }^{245}$ Many impaired drivers do not exhibit obvious signs of intoxication, and are thus able to evade detection. This low detection rate not only permits drivers who pose an ongoing risk to continue driving, but also creates a low perceived rate of apprehension. As the Supreme Court stated with respect to unlicenced drivers in Ladouceur: "To permit those whose licence is suspended to drive creates ... a danger to society and fosters a contempt for the law by the ease of infringement. There must be a real element of risk of detection of driving by unlicenced drivers for the suspension of a licence to be an effective remedy."246

RBT removes impaired drivers from the roads and deters impaired driving by sharply increasing perceived and actual rates of detection. Moreover, it has proven to be effective in many comparable democracies. Consequently, it is rationally connected to the goal of reducing impaired driving.

\section{MINIMUM IMPAIRMENT}

Experience shows that nearly all section 1 cases turn on the minimum impairment or "least drastic means" test, ${ }^{247}$ and this is likely where the challenge to RBT will be most robust. The government will need to show that RBT impairs a driver's constitutional rights as little as necessary; that is, that it is the least drastic means of achieving the government's objective. While some of this analysis must be tailored to the right in question, the overarching argument at this stage is that Canada's previous attempts to reduce impaired driving have not had a sufficient impact. In spite of concerted efforts by the federal and provincial governments, including Criminal Code amendments in 1999, 2000, 2007, and 2008, increased penalties, innovative provincial measures like short-term administrative licence suspensions, alcohol interlocks, and countless public education and awareness campaigns, the impaired driving problem persists. ${ }^{248}$ As discussed in Part II.A, above, Canada has made little progress in reducing impaired driving since 2000 and has fallen behind most developed democracies. Having established a goal of a 40 percent reduction in alcohol-related deaths and injuries, Canada's Road Safety Vision 2010 failed to achieve 81 percent of its targeted reductions, with alcohol-related deaths and injuries actually increasing in several jurisdictions. ${ }^{249}$ Clearly, far more effective measures are critically needed. The research on the relative effectiveness of RBT indicates that there is no lesser infringement on Charter rights that will achieve a significant increase in impaired driving deterrence.

Ibid.

See supra notes $46-58$ and accompanying text.

Ladouceur, supra note 223 at 1284.

Hogg, supra note 168, ch 38 at 18.

See supra notes 5-9 and accompanying text.

See supra notes 24-27 and accompanying text. 
The bulk of the "minimum impairment" debate will likely centre on the relative effectiveness of RBT and Canada's existing SBT provisions, where police are authorized to demand a breath test on an ASD only if they reasonably suspect that a driver has alcohol in his or her body. ${ }^{250}$ As discussed earlier, some have claimed that SBT is as effective as RBT and is preferable because it involves a lesser infringement of constitutional rights, particularly the right to be free from unreasonable search and seizure. Thus, to succeed under section 1, the government will have to demonstrate that the existing SBT provisions are insufficient to achieve its objective of deterring impaired driving. There is ample evidence to support this, not the least of which is that Canada's existing, moderately intensive SBT programs have had limited impact. As discussed above, traffic safety statistics from New Zealand, Ireland, and most Australian states demonstrate that RBT is more effective than SBT. ${ }^{251}$ When those jurisdictions replaced SBT with RBT, they experienced significant declines in impaired driving and related crashes. Moreover, public support for RBT actually increased after it was enacted.

RBT is also superior to breath screening using PAS devices, which are somewhat less intrusive, and thus a lesser infringement of section 8. First, while PAS devices significantly increase police officers' detection rates, they do not approach the 100 percent detection rates of RBT. ${ }^{252}$ Moreover, the devices must be held very close to the driver's mouth to function properly and may become less reliable in cold temperatures. ${ }^{253}$ Second, the introduction of PAS devices would generate its own series of legal challenges, particularly if there are passengers in the car who have been drinking. Third, PAS devices would further complicate the already time-consuming and complex process of apprehending impaired drivers. In most cases, Canadian police currently rely on the results of the driver's roadside screening test to form the requisite grounds for demanding evidentiary breath testing. Introducing PAS devices would change this two-step process into a three-step process involving three different devices. If anything, the use of PAS devices would increase the amount of time that drivers are detained. Finally, it is worth noting that while PAS devices have been approved in the US, there has been considerable police opposition to their use. ${ }^{254}$ They are not used during routine patrol activities and are used relatively infrequently even at sobriety checkpoints. ${ }^{255}$ Given these concerns about the accuracy, costs, and further complications of the enforcement

$250 \quad$ Criminal Code, supra note 41, s 254(2).

251 See Part III.B.3, above.

252 Jones \& Lund, supra note 54; Fell, Compton \& Voas, supra note 125 at 537. They are not used during routine patrol activities, and are used relatively infrequently even at sobriety checkpoints. James C Fell et al, "Why are Sobriety Checkpoints Not Widely Adopted as an Enforcement Strategy in the United States? (2003) 35 Accident Analysis \& Prevention 897 at 901. Given these concerns about accuracy, costs, and further complication of the enforcement process, PAS devices are not a reasonable alternative to RBT. Moreover, if the currently accepted systems of random searching and screening at airports, borders, courtrooms, and other government buildings satisfy the minimum impairment requirement, a far more compelling case can be made for RBT.

253 Fell, Compton \& Voas, supra note 125 at 534. The reliability of the devices in cold weather is the personal knowledge of author Robert Solomon, who has personally participated in field testing.

254 Ibid at 537. Further, since PAS devices are not currently used in Canada, they would have to be purchased by Canadian police forces at considerable expense. An American study listed the cost of PAS devices as \$500.00. Robert B Voas, John H Lacey \& James C Fell, “The Passpoint System — Passive Sensors at Minicheckpoints: Bringing Australia's Random Breath Test System to the United States" in Implementing Impaired Driving Countermeasures: Putting Research into Action (Washington, DC: Transportation Research Board, 2005) 45 at 48, online: Centers for Disease Control and Prevention $<$ http://onlinepubs.trb.org/onlinepubs/circulars/ec072.pdf $>$.

255 Fell et al, supra note 252 at 901 . See also Fell, Compton \& Voas, supra note 125 at 537, where an "optimistic" estimate of PAS use by American police was only 2,000 out of 500,000 traffic law enforcement officers. 
process, PAS devices are not a reasonable alternative to RBT. In any event, they are only marginally less intrusive than roadside screening using ASDs.

The Supreme Court of Canada has already found that the detention involved in random spot checks is a minimum impairment of section 9. In Ladouceur, for example, Justice Cory observed that "not only is the stopping of vehicles rationally connected to highway safety, it is the sole method of checking a driver's licence and insurance, or the mechanical fitness of a vehicle or whether the driver is impaired." 256 If police were not authorized to detain vehicles, they would have little opportunity to detect impaired drivers until after a crash had occurred. As Justice Cory also remarked in Ladouceur:

Surely the preventive medication of requiring drivers to stop ... is preferable to the incurable terminal tragedy represented by the fatal accident victim and the permanently disabled victim. Surely it must be better to permit the random stop and prevent the accident than to deny the right to stop and repeatedly confirm the sad statistics at the morgue and hospital. ${ }^{257}$

As discussed above, the detention involved in RBT would likely be comparable to the length of current SBT traffic stops and of minimal inconvenience to drivers. For most sober drivers it would involve a delay of only two minutes, including the waiting and testing time, and they would remain in their vehicles throughout. Further, as indicated, RBT is designed to eliminate any element of discretion or subjectivity on the part of police because all drivers entering the RBT checkpoint are subject to testing. Therefore, it is not the case that drivers would be tested based on the discretion or whim of police officers, or that any kind of "profiling" would take place. ${ }^{258}$ While the legislation would not be limited to organized spot checks, ${ }^{259}$ the program is not designed to "single out" any particular driver for testing.

Finally, like other roadside measures used to screen for impaired drivers, RBT will likely be found to be a minimum impairment of the right to counsel. ${ }^{260}$ The closest counterpart is roadside breath testing on an ASD, which was found to be a justifiable limit on the right to counsel in Thomsen. Justice Le Dain explained:

Ladouceur, supra note 223 at 1284. See also $R v$ Grunwald, 2010 BCCA 288, 257 CCC (3d) 53. Ladouceur, ibid at 1281-82.

Indeed, the author's personal experience of RBT in Australia suggests that the structure of checkpoints makes the identification or "profiling" of drivers extremely difficult. The position of the officers who control the flow of traffic to allow for braking and safe entry into the checkpoint is such that they cannot observe the individual characteristics of drivers.

As indicated, the power to conduct RBT during routine police patrol activities is particularly important late at night, in rural areas and in other circumstances in which low traffic volumes do not warrant establishing a stationary RBT checkpoint. Nevertheless, it may be contended that mobile RBT checks will be difficult to justify under section 1 of the Charter because they rely upon an individual officer's discretion and thus may be more prone to abuse. This argument is not compelling. First, it must be noted that mobile RBT has been shown to play a central role in increasing the perceived risks of apprehension and thus the deterrent impact of the impaired driving law. In the absence of mobile RBT, a significant number of drivers will believe, with some reason, that they can continue to evade detection. See generally supra note 70 and accompanying text. This permits drivers to play, in the words of one researcher, "breathalyzer roulette." Homel, "Random Breath Testing the Australian Way," supra note 49 at 72 . Second, thousands of border guards, airport security staff, and other similar personnel exercise discretion on a daily basis in determining who is subject to detailed questioning, screening, and searching. Given that these individuals' discretionary powers have been upheld under section 1, it is difficult to see how a different conclusion could be reached in regard to the police, who are more highly trained. Third, and most importantly, the Supreme Court of Canada has already upheld the random stopping of drivers at both sobriety checkpoints and during routine patrol activities. Hufsky, supra note 204; Ladouceur, supra note 223; Orbanski, supra note 39.

Thomsen, supra note 228; Orbanski, ibid. 
The important role played by roadside breath testing is not only to increase the detection of impaired driving, but to increase the perceived risk of its detection, which is essential to its effective deterrence. In my opinion the importance of this role makes the necessary limitation on the right to retain and instruct counsel at the roadside testing stage a reasonable one that is demonstrably justified in a free and democratic society, having regard to the fact that the right to counsel will be available, if necessary, at the more serious breathalyzer stage. $^{261}$

In Justice Le Dain's view, the need to conduct the ASD test quickly at roadside simply did not allow for a prior opportunity to consult counsel.

The logic of Thomsen applies with even more force to RBT. As indicated, the effectiveness of RBT depends on police being able to process the maximum number of drivers in a minimum amount of time: it is the high rate of testing that contributes to the increased perception of detection. This deterrent purpose would be frustrated if every driver were able to consult counsel. This is particularly true given that the highest incidence of impairment occurs late at night and early in the morning, when the probability of a detained person immediately obtaining legal advice is very low. ${ }^{262}$ If each driver were given an opportunity to consult counsel before taking an ASD test, the RBT program would grind to a halt. RBT can only be effective if it operates in violation of the right to consult counsel.

Further, RBT is used as a preliminary screening tool only and its results do not directly attract any criminal consequences. If the results of the test indicate that a driver has a BAC above the Criminal Code limit, the driver will be given the right to retain and instruct counsel prior to any evidentiary breath tests. ${ }^{263}$ Finally, while the importance of the right to consult counsel cannot be downplayed, the practical effect of any legal advice given at roadside would be minimal. Unless something is very amiss, drivers have an obligation to comply with the demand and the only advice counsel could provide would be to provide a breath sample. ${ }^{264}$ Therefore, section $10(\mathrm{~b})$ is infringed as little as possible.

\section{PROPORTIONALITY}

The final part of the Oakes test requires that there be proportionality between the deleterious and salutary effects of the measure, and that the effects of the impugned law not be so severe that they outweigh the importance of the legislative objective. ${ }^{265}$ In other words, it asks "whether the Charter infringement is too high a price to pay for the benefit of the law." ${ }^{266}$ It has been suggested that this part of the test is redundant and has never affected the

Thomsen, ibid at 655 .

See Seo, supra note 210 at 316.

This was seen as crucial in Orbanski, supra note 39, where the results of police questioning and field sobriety testing were not admissible in evidence at trial, but were used to form the grounds for demanding an evidentiary breath test on an approved instrument. The accused were permitted to consult counsel before providing the evidentiary breath samples. See also $R v$ Milne (1996), 28 OR (3d) 577 (CA).

Under section 254(5) of the Criminal Code, supra note 41, it is an offence to fail or refuse to supply a breath sample without a reasonable excuse. While it is beyond the scope of this paper, there are only rare circumstances where prudent counsel would advise a driver to refuse to take a breath test.

Dagenais v Canadian Broadcasting Corp, [1994] 3 SCR 835 at 889.

Hogg, supra note 168 , ch 38 at 43 . 
outcome of a case. ${ }^{267}$ Nevertheless, we provide some brief comments here for the sake of completeness. Given our previous analysis, RBT should pass the proportionality test.

Reducing impaired driving has been repeatedly cited as a very important objective. Every year, impairment related crashes kill roughly twice as many Canadians as all homicides combined. In spite of increased sentences and innovative provincial countermeasures, impaired driving remains a significant problem in Canada. To address similar concerns, most comparable democracies have introduced RBT with significant traffic safety benefits. In fact, it is typically cited as the most effective impaired driving countermeasure. Thus, the objectives and potential benefits of introducing RBT in Canada are substantial.

On the other hand, RBT's effects on individual rights are relatively modest. For most drivers, RBT will cause a momentary delay and slight inconvenience. Providing a breath sample on an ASD is minimally intrusive and is not embarrassing or humiliating, particularly because every driver entering the RBT checkpoint will be required to provide one. There is accordingly no stigma involved. The results of the ASD test are transitory and used for screening purposes only. Should a driver be asked to provide evidentiary breath samples, all the normal protections that apply on arrest, including the right to consult counsel, would apply.

Further, in considering the effects of RBT it should be stressed that all road users, including those who are tested, benefit from the law's deterrent effect. RBT not only removes current impaired drivers from the roads, but it discourages others from driving after drinking in the future. All road users are "beneficiaries" of RBT and this helps to explain why it is strongly supported by the public in Canada and abroad. It is apparent that the great majority of Canadians believe that RBT's benefits justify any intrusion on drivers that it may entail.

\section{ConCLuSion}

Despite various amendments, initiatives, and campaigns, the percentage and number of impairment related crash deaths and injuries have changed little since 2000. Canada, which has a relatively modest rate of per capita alcohol consumption, continues to have a very poor impaired driving record by international standards. Given the current law and recent trends, little to no progress is likely. Faced with similar challenges in deterring impaired driving, most comparable democracies have implemented comprehensive RBT programs. Individual studies, research reviews, and meta-analyses have consistently found that these programs achieve significant and sustained reductions in impaired driving deaths and injuries. ${ }^{268}$ Consistent with the other international research, a recent New Zealand study described RBT 567 at paras 75-76, Chief Justice McLachlin, where Professor Hogg's analysis was rejected (but where "proportionality" still did not affect the outcome of the case). Hogg remains apparently unpersuaded in his most recent looseleaf: Hogg, ibid, ch 38 at 44.2. supra note 28 at 170-72; Robin Room, Thomas Babor \& Jürgen Rehm, "Alcohol and Public Health" (2005) 365 Lancet 519 at 526; WHO, 2004, supra note 106 at 30; Grube, supra note 106 at 104-105; Donald A Brand et al, "Comparative Analysis of Alcohol Control Policies in 30 Countries" (2007) 4:4 PLoS Medicine 0752 at 0753; Peter Anderson, Dan Chisholm \& Daniela C Fuhr, "Effectiveness and Cost-Effectiveness of Policies and Programmes to Reduce the Harm Caused by Alcohol" (2009) 373 Lancet 2234 at 2238 . 
as the best proven impaired driving countermeasure, stating that: "In both [New Zealand] and at least one Australian state, intensive [RBT] appears to have halved the alcohol-related crash death toll relative to a time without random breath testing." ${ }^{269}$

RBT is also widely recognized as the most cost-effective means of deterring impaired driving. The more comprehensive and intensive the RBT program, the greater its cost-benefit ratio. Motorists stopped at RBT checkpoints are subject to minor delay and minimum inconvenience. These programs enjoy extremely high levels of public support, which generally increase following their implementation. RBT legislation will inevitably be subject to various Charter challenges. However, like current courthouse, customs, and airport screening and search procedures and existing traffic enforcement powers, RBT is compatible with Charter values. 